\title{
On the development of a trait-based approach for studying Neotropical bats
}

\author{
Dennis Castillo-Figueroa ${ }^{1,2}$ \& Jairo Pérez-Torres ${ }^{1,3}$ \\ 1 Pontificia Universidad Javeriana (PUJ), Facultad de Ciencias, Departamento de Biología, Unidad de Ecología y Sistemática (UNESIS), \\ Laboratorio de Ecología Funcional. Bogotá, Colombia. \\ 2 ORCID: http://orcid.org/0000-0002-4584-0762. E-mail: dennis.castillof@gmail.com (corresponding author) \\ 3 ORCID: http://orcid.org/0000-0001-7121-6210.E-mail: jaiperez@javeriana.edu.co
}

\begin{abstract}
New World bats are involved in key ecological processes and are good indicators of environmental changes. Recently, trait-based approaches have been used in several taxa to better understand mechanisms underlying species assemblages, biotic interactions, environmental relationships and ecosystem functions. However, despite the relevance of bats on ecosystem dynamics, so far, there is no conceptual framework that relies on the measurement of bat traits to address functional studies. Here, we present a set of 50 bat biological traits, which are suitable to assess environmental stressors and can potentially affect ecological processes. Several examples were provided to show the applicability of this framework in the study of Neotropical bat ecology. We suggest some considerations regarding trait-based approach including the importance of intraspecific variation, correlations between traits, response-effect framework, global dataset, and future directions to assess the reliability of functional relations across species and Neotropical regions by using traits. This could be helpful in tackling ecological questions associated with community assembly and habitat filtering, species diversity patterns along environmental gradients, and ecological processes. We envision this paper as a first step toward an integrative bat functional trait protocol held up with solid evidence.
\end{abstract}

Keywords. Chiroptera; Ecosystem functions; Functional traits; Morphology; Life-history.

\section{INTRODUCTION}

Global biodiversity loss is a major concern that has motivated ecologists to explore the links between biodiversity and ecosystem functioning (Gross et al., 2017), especially under different scenarios of human impact (García-Morales et al., 2016). The necessity to transfer this knowledge into management planning is critical, as the massive loss of biodiversity is threatening the ecosystem services from which humans depend on (Millennium Ecosystem Assessment, 2005). Accordingly, several approaches have been conducted to monitor biodiversity, of which measures of taxonomic diversity (i.e., species richness, evenness, diversity) are the most widely used ones (Cadotte et al., 2011; Mayfield et al., 2010; García-Morales et al., 2016). However, taxonomic diversity indices (e.g., Shannon, Simpson) ignore species differences in ecological roles (Villéger et al., 2010; Córdova-Tapia \& Zambrano, 2016). Alternatively, functional diversity approach has been a core topic research in community ecology and conservation biology over the last decades (García-Morales et al., 2016; Gross et al., 2017), due to the inclusion of ecological attributes of species associated to ecosystem functioning (GómezOrtiz \& Moreno, 2017). In line with this, functional diversity provides a comprehensive framework of causes, consequences, and mechanisms in the relations between species diversity and ecological processes (Córdova-Tapia \& Zambrano, 2016).

Moving from ecological studies based on the taxonomic structure of communities to investigations that include functional diversity measures and relationships with ecosystem processes requires, mainly, a functional trait-based approach. Functional traits are traditionally defined as any morphological, physiological, behavioral, or phenological characteristic that, in addition to impact the fitness of an organism (Violle et al., 2007), reflects interactions with the environment either by mirroring the impact on some ecosystem process (effect traits) (Lavorel \& Garnier, 2002; Luck et al., 2012) and/or by responding to environmental changes (response traits). Values measured by a functional trait in the same spatio-temporal dimension are called functional attributes (Lavorel et al., 1997). Thus, functional trait-based approach is a promising tool to address plenty of ecological questions that contribute to biodiversity conservation (Castillo-Figueroa, 2018a; Jung \& Threlfall, 
2018). For example, several studies show that functional traits explain the impact of human-made landscapes on ecological groups of animals (Castillo-Figueroa \& PérezTorres, 2018), the influence of climate change on species distributions and phenology (Robbirt et al., 2011), the effect of chemical elements on community assembly (Rubach et al., 2011; Van den Brink et al., 2013), and the distribution of functional diversity at macro-ecological scale (McGill et al., 2006; Hortal et al., 2015; GonzálezMaya et al., 2017), to name a few examples.

The concept of functional traits has been, however, criticized because of its vague meaning, as all the traits of an organisms affect, at least indirectly, the fitness of an individual (Mlambo, 2014). Focusing on functionality rather than the performance of the organism seems to be a more comprehensive definition of functional trait. Hence, real functional traits are those that modulate ecological processes, whereas the other traits can be categorized as biological ones (Mlambo, 2014). In this sense, before reaching functional traits is essential to list, describe and study biological traits that can potentially be functional.

Plant communities are the main biological group in which functional trait-based approach has been widely developed (Cornelissen et al., 2003; Hortal et al., 2015). Plant ecologists have been able to conceptualize the linkages between individual plant traits and ecosystem processes, including mechanisms and ecological factors such as competition, intra- and inter-specific variation, and environmental filtering across several ecosystems (Siefert et al., 2015). This field has advanced in the last few years with global databases like TRY (Kattge et al., 2020), LEDA (Kleyer et al., 2008) Global Wood Density (Chave et al., 2009), as well as handbooks and protocols (Cornelissen et al., 2003; Salgado-Negret et al., 2015). Undoubtedly, plant functional trait-based approaches have been a successful model that animal ecologists have adopted in handbooks and frameworks of traits in zoological groups such as terrestrial invertebrates (Moretti et al., 2017), fishes (Zamudio et al., 2015), birds (LópezOrdoñez et al., 2015), and amphibians (Cortés-Gómez et al., 2015). Nevertheless, so far, there is no such protocol for mammalian traits, mainly due to the challenge of developing a single handbook that integrates the striking ecological complexity of this group. Although several but isolated investigations using functional traits have been conducted in mammals, it is necessary to start selecting biological traits of mammal groups to accomplish a complete and solid functional trait handbook.

Chiroptera is one of the most ecologically important taxa among mammals. Accounting for 1,411 recognized species (Mammal Diversity Database, 2020), bats represent a fifth of mammalian diversity (Hutson et al., 2001; Frick et al., 2019), with many opportunities for investigating ecological questions in a comparative framework (Brokaw \& Smotherman, 2020). New World bats, in particular, consist of 400 species (Arita et al., 2014) and display a variety of morphological (Findley et al., 1972; Santana et al., 2011a, 2012; Castillo-Figueroa, 2020a), ethological (Vandoros \& Dumont, 2004; Voss et al., 2016;
Castillo-Figueroa et al., 2018), physiological (Schondube et al., 2001; Saldaña-Vázquez et al., 2015; Tschapka et al., 2015), and reproductive traits (Fleming et al., 1972; Kerth, 2008; Vela-Vargas et al., 2016; Stukenholtz et al., 2018). Moreover, this group has a high diversity of feeding habits (Wilson, 1973), trophic niches (Giannini \& Kalko, 2004), and habitat use (Kalko et al., 2008; Denzinger \& Schnitzler, 2013; Voss et al., 2016), which are reflected in their multiple ecological roles in the ecosystems they inhabit (Lacher et al., 2019; Castillo-Figueroa, 2020b). Even though ecological studies using traits have long been conducted in bats (Findley \& Wilson, 1982; Norberg \& Rayner, 1987; Fleming, 1991), recently some investigations have focused on functional diversity measures based on traits (Pereira et al., 2018; Mancini et al., 2019; Pereira et al., 2019; Farneda et al., 2019; Ramírez-Mejía et al., 2020), many of which have lacked an ecological criterion to select the most suitable functional traits. Because the success of trait-based approaches depends on trait selection (Hortal et al., 2015), conceptual frameworks that define the ecological relations of traits becomes imperative to better apply this approach into functional ecology studies. Here, we present a synthetic conceptual framework which emphasizes in the main biological traits of Neotropical bats by defining an extensive set of features. We then show how our framework might aid to perform different studies on bat ecology through several examples from literature that includes: trait-related responses to habitat fragmentation, land use management, elevational gradients, seasonal changes and seed dispersal networks. We also emphasize the importance of testing, either empirically or experimentally, these biological traits in order to discover the real functionality of each trait. Finally, we discuss issues regarding trait-based approach in Neotropical bats encompassing intraspecific variation, correlations between traits, response-effect framework, global dataset, and future directions regarding their application in functional ecology and biodiversity conservation.

\section{MATERIAL AND METHODS}

\section{Functional ecology and trait selection}

Neotropical bats play key ecological roles in arthropod suppression, vertebrate predation, seed dispersal, pollination, and fertilization (Kasso \& Balakrishnan, 2013; Castillo-Figueroa, 2020b). Furthermore, bats have broad geographical ranges and can be affected by several environmental gradients including habitat fragmentation (Meyer et al., 2008, 2016; Rocha et al., 2017), agricultural management (Castillo-Figueroa \& Pérez-Torres, 2018), urbanization (Jung \& Threlfall, 2018), climate change (Sherwin et al., 2012), among others. In fact, bats have been considered as bioindicators of disturbance due to idiosyncratic responses to environmental variation (Fenton et al., 1992; Medellín et al., 2000; Jones et al., 2009a). Consequently, effect and response traits may reflect the relations with ecological processes and the 
impact of environmental conditions on this group, yet there are few studies using functional traits and, in most cases, the selection seems to be arbitrary because of the absence of functional interpretations of traits. Easy measurable traits are usually chosen, rather than traits more related to functional components (Raunkiaeran Shortfall sensu Hortal et al., 2015).

We selected 50 bat biological traits according to studies that directly relate traits to environmental conditions, but we also included traits potentially linked to, either directly or indirectly, individual performance and ecosystem process (Table 1). However, more research is needed to clarify direct linkages with ecosystem functioning as the available information that relates traits with ecological processes is very scarce. This paper, therefore, helps to provide a list of potential traits that need to be investigated in-depth for an understanding of their functionality.

The selected traits were grouped into two main types of traits: Morphological (21 traits) and Life history traits (29 traits) (Fig. 1). The former includes six functional complexes (size, wings, pollex, hindlimbs, head, and tail) and the latter is divided into six functional dimensions following the proposal of Gómez-Ortiz \& Moreno (2017): reproductive, physiological, behavioral, trophic niche, spatial niche, and echolocation (Table 1). We focused on the selection of traits that can be measured directly and quantitatively, but we also presented categorical traits, which have been extensively used in several ecological studies (Cisneros et al., 2016; Castillo-Figueroa \& PérezTorres, 2018; Farneda et al., 2019; Ramírez-Mejía et al., 2020). In all the traits we indicated the pertaining group (functional complex or functional dimension), the value of the trait (attribute), the way to measure (description), and the source of information where the trait can be obtained (trait obtaining). We also present the ecological information of each trait based on an extensive literature revision of bat ecology.

\section{Study cases from literature}

We reviewed the available information that employed the usage of trait-based approach in Neotropical bats by searching in Scopus and Google scholar databases (consulted the 25/09/2020) with the terms "Neotropical Bats" OR "New World bats" AND "Trait-based approach". We obtained 135 document results from Scopus and 541 from Google Scholar. After reviewing carefully each one of the documents we obtained a total of 19 study cases that employed this approach. For each case we recorded location, morphological and natural history traits, and the application of the study. Five of those cases were illustrated to show the type of research questions that can be pursued under trait-based approach.

\section{RESULTS}

\section{Morphological Traits}

\section{Size complex}

Body size is probably one of the most informative traits, and it is also one of the easiest features to measure in bats (MacNab, 2007; Safi et al., 2013; Giannini et al., 2012). In the past few years, body size has been the core of ecological and evolutionary studies (Safi et al., 2013;

\section{LIFE HISTORY TRAITS}

Functional dimension

Reproductive Litters per year Litter size Gestation duration Lactation duration Reproductive status Sexual maturity age Mating systems Digestive capacty $\boldsymbol{C}$ Gut size

Physiological • Gut retention time of seeds $C$ Type of lingual papillae Metabolic rate papillae Metabolic rate temperature

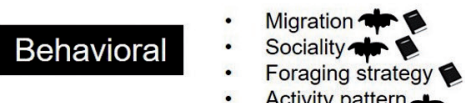

- Activity pattern

Trophic niche $\cdot$ Diet specialization Bite force trizen Foraging habitat Spatial niche Vertical stratification Home range tre Type of roost Duration

Echolocation Frequency
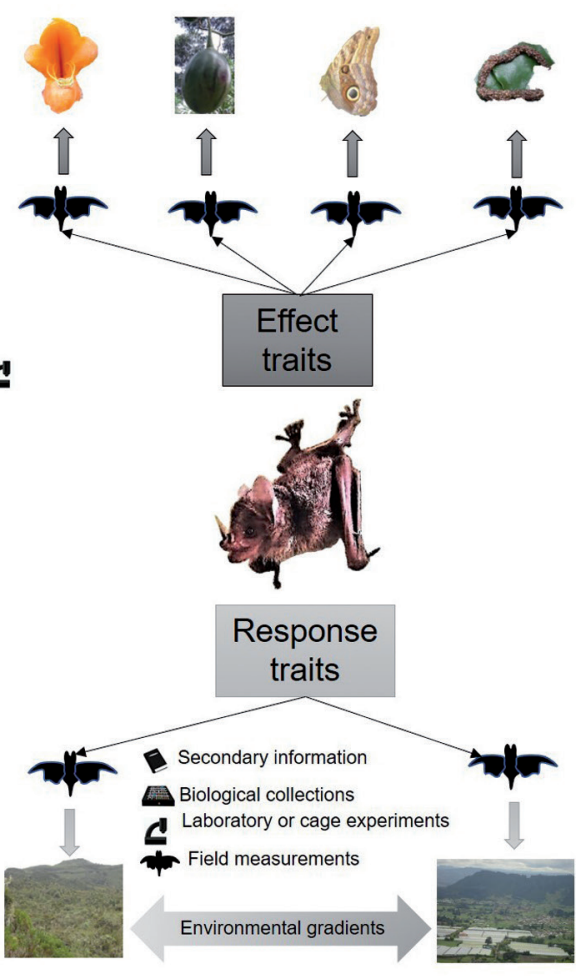

MORPHOLOGICAL TRAITS

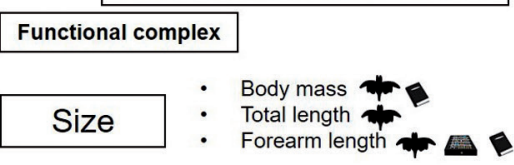

Forearm length

Length of the third digit Length of the fifth digit Wing loading the Aspect ratio Tr Aspect ratio ir Wing span Tip shape index

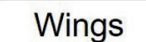
Length of the pollex without claw Length of the with claw

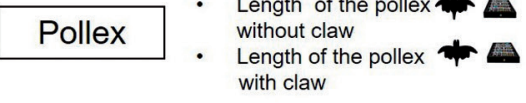

Length of the foot without claw Length of the foot 1 r r with claw

Length of the tibia

Length of calcaneus

Length of the ear Length of the tragus Length of the tragus aror Length of the nose leaf
Inner nostril width ratio Intensity

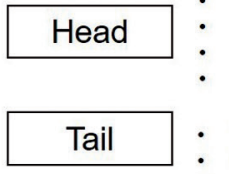

Tail length Uropatagium area

Figure 1. Schematic model of biological traits of Neotropical bats. Life history traits in black boxes whereas morphological traits are depicted in white boxes. 
Table 1. Biological traits of Neotropical bats. Morphological traits are grouped into six functional complexes and life history traits are classified into six functional dimensions. In trait obtention: $\mathrm{SI}=$ secondary information, $\mathrm{FM}=$ field measurement, $\mathrm{BC}=$ Biological collections, $\mathrm{LE}=$ laboratory or cage experiments.

\begin{tabular}{|c|c|c|c|c|c|}
\hline Trait type & $\begin{array}{l}\text { Complex or } \\
\text { functional } \\
\text { dimension }\end{array}$ & Trait & Attribute & $\begin{array}{l}\text { Trait } \\
\text { obtention }\end{array}$ & Description of the trait \\
\hline \multirow[t]{21}{*}{ Morphological } & \multirow[t]{3}{*}{ Size } & Body mass & Value of the trait in grams $(\mathrm{g})$ & $\mathrm{SI}, \mathrm{FM}$ & Based on weight \\
\hline & & Total length & Value of the trait in millimeters (mm) & FM & $\begin{array}{l}\text { Measurement from the tail (if any) to the head (tail + body + head). If there is } \\
\text { no tail, the measurement encompasses the lower end of the body to the head }\end{array}$ \\
\hline & & Forearm length & Value of the trait in millimeters $(\mathrm{mm})$ & $\mathrm{SI}, \mathrm{FM}, \mathrm{BC}$ & $\begin{array}{l}\text { Measurement from the base of the elbow (tip of the olecranon process) to the } \\
\text { distal region of the forearm where it joins the carpus }\end{array}$ \\
\hline & \multirow[t]{6}{*}{ Wings } & Length of the third digit & Value of the trait in millimeters (mm) & $\mathrm{FM}, \mathrm{BC}$ & $\begin{array}{l}\text { In biological collections the trait is the result of the sum of the metacarpus and its } \\
\text { three phalanges. The metacarpus is measured from the joint with the phalanx to } \\
\text { the junction with the carpus. The phalanx is measured as the maximum distance } \\
\text { between the joints. In the field, the trait is measured from the junction of the } \\
\text { metacarpus with the carpus to the tip of the third phalanx }\end{array}$ \\
\hline & & Length of the fifth digit & Value of the trait in millimeters (mm) & $\mathrm{FM}, \mathrm{BC}$ & $\begin{array}{l}\text { In biological collections the trait is the result of the sum of the metacarpus and } \\
\text { its two phalanges. The metacarpus is measured from the joint with the phalanx } \\
\text { to the junction with the carpus. The phalanx is measured as the maximum } \\
\text { distance between the joints. In the field, it is measured from the junction of the } \\
\text { metacarpus with the carps to the tip of the second phalanx }\end{array}$ \\
\hline & & Wing loading & Value of the trait in Newtons $/ \mathrm{m}^{2}$ & $\mathrm{FM}, \mathrm{SI}$ & $\begin{array}{l}\text { Wing loading }(\mathrm{Wl}) \text { is body mass in kg times acceleration of gravity }(\mathrm{Mg}) \text { divided } \\
\text { by its wing area in } \mathrm{m}^{2}(\mathrm{~S}) ;{ }^{*} \text { gravity acceleration }=9.8 \mathrm{~m} / \mathrm{s}^{2} ; \mathrm{Wl}=\mathrm{Mg} / \mathrm{S}\left(\mathrm{N} / \mathrm{m}^{2}\right)\end{array}$ \\
\hline & & Aspect ratio & Adimensional (numerical) & $\mathrm{FM}, \mathrm{SI}$ & $\begin{array}{l}\text { Aspect ratio }(A) \text { is the result of the wing span squared }\left(m^{2}\right)(B) \text { divided by wing } \\
\text { area }\left(m^{2}\right)(S) ; A=B^{2} / S\end{array}$ \\
\hline & & Tip shape index & Adimensional (numerical) & $\mathrm{FM}, \mathrm{SI}$ & $\begin{array}{l}\text { Tip shape index (I) is the tip area ratio (Ts) divided by tip length ratio (TI) minus } \\
\mathrm{Ts} ; \mathrm{I}=\mathrm{Ts} /(\mathrm{TI}-\mathrm{Ts})\end{array}$ \\
\hline & & Wing span & Value of the trait in millimeters (mm) & $\mathrm{FM}, \mathrm{SI}$ & $\begin{array}{l}\text { Measurement taken from tip to tip of the extended wings held along to the long } \\
\text { axis of the body }\end{array}$ \\
\hline & \multirow[t]{2}{*}{ Pollex } & Length of the pollex without claw & Value of the trait in millimeters (mm) & $\mathrm{FM}, \mathrm{BC}$ & $\begin{array}{l}\text { Measurement from the beginning of the phalanx of finger to the beginning of } \\
\text { the claw }\end{array}$ \\
\hline & & Length of the pollex with claw & Value of the trait in millimeters (mm) & $\mathrm{FM}, \mathrm{BC}$ & $\begin{array}{l}\text { Measurement from the beginning of the phalanx of the thumb to the tip of the } \\
\text { claw }\end{array}$ \\
\hline & \multirow[t]{4}{*}{ Hindlimbs } & Length of the foot without claw & Value of the trait in millimeters (mm) & $\mathrm{FM}, \mathrm{BC}$ & Measurement from the joint with the tibia to the beginning of the claws \\
\hline & & length of the foot with claw & Value of the trait in millimeters (mm) & $\mathrm{FM}, \mathrm{BC}$ & Measurement from the tibia joint to the tip of the claw \\
\hline & & Length of the tibia & Value of the trait in millimeters (mm) & $\mathrm{FM}, \mathrm{BC}$ & Measurement from the joint with the femur to the joint with the foot \\
\hline & & Length of calcaneus & Value of the trait in millimeters (mm) & $\mathrm{FM}, \mathrm{BC}$ & Measure from the base of the calcaneus to the tip of it \\
\hline & \multirow[t]{4}{*}{ Head } & Length of the ear & Value of the trait in millimeters (mm) & FM & Measure from the base of the ear to its most apical region \\
\hline & & Length of tragus & Value of the trait in millimeters $(\mathrm{mm})$ & FM & Measure from the base to the tip of the structure \\
\hline & & Length of nose leaf & Value of the trait in millimeters (mm) & $\mathrm{FM}, \mathrm{BC}$ & Measurement from the base of the nasal horseshoe to the tip of the lancet \\
\hline & & Inner nostril width ratio & Adimensional (numerical) & $\mathrm{FM}, \mathrm{BC}$ & Ratio of the cranial width to the inner nostril width \\
\hline & \multirow[t]{2}{*}{ Tail } & Tail length & Value of the trait in millimeters (mm) & FM & Measurement from the insertion of the tail in the body to its distal end \\
\hline & & Uropatagium area & Value of the trait in area $\left(\mathrm{m}^{2}\right)$ & FM & Measurement of the surface area of the intrafemoral membrane \\
\hline \multirow[t]{10}{*}{ Life history } & \multirow[t]{7}{*}{ Reproductive } & $\underline{\text { Litters per year }}$ & Mean number of litters during a year & $\mathrm{FM}, \mathrm{SI}$ & Number of litters produced per year \\
\hline & & $\underline{\text { Litter size }}$ & Mean number of pups per litter & $\mathrm{FM}, \mathrm{SI}$ & Number of pups produced per litter \\
\hline & & Gestation duration & Mean days in pregnancy & $\mathrm{FM}, \mathrm{SI}$ & Length of the pregnancy expressed in days \\
\hline & & Lactation duration & Mean days in lactation & $\mathrm{FM}, \mathrm{SI}$ & Length of the lactation expressed in days \\
\hline & & Reproductive status & $\begin{array}{l}\text { For females the frequencies or } \\
\text { population averages of each stage: } \\
\text { Proestrus. Estrus. Metestrus. Anestrus. } \\
\text { For males the frequencies or population } \\
\text { averages of: Scrotted males Non- } \\
\text { scrotted males }\end{array}$ & FM & $\begin{array}{l}\text { Reproductive stage that involves hormonal concentration (progesterone } \\
\text { and estradiol peaks) and physiological changes in females (corpus luteum } \\
\text { and ovarian follicle). Vaginal smears can reveal superficial nucleated cells } \\
\text { (proestrus), superficial non-nucleated cells parabasal (estrus), intermediate } \\
\text { cells (metestrus) and parabasal cells (anestrus) in bat females. Females can be } \\
\text { considered reproductive when they presented a dominance in proestrus, estrus, } \\
\text { and metestrus. By contrast, non-reproductive females are when the dominant } \\
\text { stage is anestrus. This can be measured individually and can also be expressed } \\
\text { in frequencies or population averages of each stage. For males, reproductive } \\
\text { status can be determined by examining testes (scrotted or not), thus obtaining } \\
\text { frequencies or population averages of each condition. }\end{array}$ \\
\hline & & Sexual maturity age & Mean number of years & $\mathrm{FM}, \mathrm{SI}$ & Age at first reproductive event (adult) \\
\hline & & Mating systems & $\begin{array}{l}\text { Monogamic; Polygyny; Polyandry; } \\
\text { Promiscuty }\end{array}$ & $\mathrm{FM}, \mathrm{SI}$ & $\begin{array}{l}\text { All the potential combinations between bats to find mate and copulate during } \\
\text { reproductive season }\end{array}$ \\
\hline & \multirow[t]{3}{*}{ Physiological } & Digestive capactiy & Food intake response & LE & $\begin{array}{l}\text { Bat capacity to obtain nutrients when consumption item differ in nutrient } \\
\text { quality. Food intake response is defined as the relationship (following power } \\
\text { function) between volumetric food intake and nutrient concentration }\end{array}$ \\
\hline & & Gut size & Mean surface area $\left(\mathrm{cm}^{2}\right)$ & $\mathrm{BC}$ & Gut area of the total gut \\
\hline & & Gut retention time of seeds & Mean number of time (minutes) & LE & $\begin{array}{l}\text { Time that the seeds are retained inside the gut of the bat until is expelled by } \\
\text { feces }\end{array}$ \\
\hline
\end{tabular}




\begin{tabular}{|c|c|c|c|c|c|}
\hline \multirow{4}{*}{\multicolumn{2}{|c|}{$\begin{array}{l}\text { Complex or } \\
\text { functional } \\
\text { dimension }\end{array}$}} & Trait & Attribute & \multirow[t]{2}{*}{$\begin{array}{l}\text { Trait } \\
\text { obtention }\end{array}$} & \multirow[t]{2}{*}{ Description of the trait } \\
\hline & & Type of lingual papillae & $\begin{array}{l}\text { Gustative, including vallate and } \\
\text { fungiform, or mechanical comprising } \\
\text { basal, postero-median, scalelike, } \\
\text { filiform, foliate, conical, and horny }\end{array}$ & & \\
\hline & & Metabolic rate & Mean energetic expenditure (kcal/day) & FM, LE & $\begin{array}{l}\text { Energy unit per time required by an individual to maintain its basal physiological } \\
\text { functions }\end{array}$ \\
\hline & & Body temperature & $\begin{array}{l}\text { Mean and ranks of body temperature } \\
\left({ }^{\circ} \mathrm{C}\right)\end{array}$ & $\mathrm{FM}, \mathrm{LE}$ & $\begin{array}{l}\text { Individual capacity to survive at a specific temperature, either hot or cold } \\
\text { temperatures }\end{array}$ \\
\hline \multirow{4}{*}{\multicolumn{2}{|c|}{ Behavioral }} & Migration & Resident; Migratory & $\mathrm{FM}, \mathrm{SI}$ & Species movement according its life history \\
\hline & & Sociality & $\begin{array}{l}\text { Solitary; Society; Group; Colony; } \\
\text { Aggregation }\end{array}$ & $\mathrm{FM}, \mathrm{SI}$ & Clustering of individuals \\
\hline & & Foraging strategy & $\begin{array}{l}\text { Gleaning foragers; Aerial foragers; } \\
\text { Trawling foragers }\end{array}$ & $\mathrm{SI}$ & Behavioral strategy that is used to obtain food \\
\hline & & Activity pattern & $\begin{array}{l}\text { Number of recording events per time } \\
\text { hour }\end{array}$ & $\mathrm{FM}$ & $\begin{array}{l}\text { Activity period of bat species within nocturnal time. Commonly spanned from } \\
\text { 18:00h to 6:00h }\end{array}$ \\
\hline \multirow{3}{*}{\multicolumn{2}{|c|}{ Trophic niche }} & Feeding guild & $\begin{array}{l}\text { Necterivore; Frugivore; Carnívore; } \\
\text { Omnívore; Sanguinivore; Insectívore; } \\
\text { Piscívore }\end{array}$ & SI & Based on the food item that is consumed mainly for a large part of bat life \\
\hline & & Diet specialization & $\begin{array}{l}\text { Value of the niche breadth index } \\
\text { selected (e.g., Levin, Morisita, etc.) } \\
\text { ranging from low values (specialist) to } \\
\text { high values (generalist) }\end{array}$ & $\mathrm{FM}$ & $\begin{array}{l}\text { Based on the percentage of the contribution of each food item to the total } \\
\text { diet the species. Levin index as well as Morisita index can estimate dietary } \\
\text { specialization }\end{array}$ \\
\hline & & Bite force & Maximum bite force (Newtons) & $\mathrm{FM}, \mathrm{BC}, \mathrm{SI}$ & $\begin{array}{l}\text { Is the result of the interplay between the teeth, the masticatory muscles, } \\
\text { the mandible, the maxillae, and temporomandibular joints. Bite force can be } \\
\text { measured in vivo with an isometric Kistler force transducer or can be estimated } \\
\text { with assessments of muscular and bony morphology from skulls using } \\
\text { algorithms }\end{array}$ \\
\hline \multirow{4}{*}{\multicolumn{2}{|c|}{ Spatial niche }} & Foraging hábitat & $\begin{array}{l}\text { Background space; Uncluttered space; } \\
\text { Highly cluttered space }\end{array}$ & $\mathrm{SI}$ & $\begin{array}{l}\text { It is the space where the bat is found most of the time, especially when searching } \\
\text { for food. Resource availability and conditions limit foraging habitat }\end{array}$ \\
\hline & & Vertical stratification & $\begin{array}{l}\text { Capture rate (individuals per mist-net } \\
\text { hour) in each strata: Understory; Canopy }\end{array}$ & FM & $\begin{array}{l}\text { Based on the proportion of bat capture rate in ground (shrubs) and canopy nets } \\
\text { (treetops). Bats can also use both strata (no preference) }\end{array}$ \\
\hline & & Home range & $\begin{array}{l}\text { Mean surface area traveled during a } \\
\text { period of time }\left(\mathrm{km}^{2}\right)\end{array}$ & $\mathrm{FM}, \mathrm{SI}$ & $\begin{array}{l}\text { Area of available habitat over which an individual does its daily activities. There } \\
\text { are several ways to estimate home range such as minimum convex polygon, } \\
\text { minimum area probabilities, areas of kernel, etc. }\end{array}$ \\
\hline & & Type of roost & $\begin{array}{l}\text { Animal burrow or hole; Termite ant/ } \\
\text { nest; Cavity in fallen tree; Cavity in } \\
\text { standing tree; Exposed on standing tree; } \\
\text { Foliage, leaf tent; Foliage, unmodified } \\
\text { foliage; Rocks, crevices, or caves; Under } \\
\text { fallen tree; Undercut earth bank }\end{array}$ & $\mathrm{FM}, \mathrm{SI}$ & Diurnal roosts used by bats \\
\hline \multirow{5}{*}{\multicolumn{2}{|c|}{ Echolocation }} & Duration & Time (ms) & $\mathrm{FM}, \mathrm{SI}$ & Time span of the call emitted by the bat \\
\hline & & Interval & Time (ms) & $\mathrm{FM}, \mathrm{SI}$ & Time between one call to another emitted by the bat \\
\hline & & Frequency & Pitch of a sound (Khz) & $\mathrm{FM}, \mathrm{SI}$ & $\begin{array}{l}\text { Number of pressure waves of the call emitted by the bat that pass by a reference } \\
\text { point per unit time. This can include the start of the call (initial frequency), } \\
\text { the end of the call (final frequency) and the maximum amplitude of the call } \\
\text { (maximum frequency) }\end{array}$ \\
\hline & & Intensity & Strength of the tone signal (db) & $\mathrm{FM}, \mathrm{SI}$ & Height of the sound pressure wave emitted by the bat \\
\hline & & Harmonics & Number or harmonics (if any) & $\mathrm{FM}, \mathrm{SI}$ & Wave that is a multiple of the fundamental frequency emitted by the bat \\
\hline
\end{tabular}

Giannini et al., 2012; Arevalo et al., 2020). Size has remarkable implications in essential functions such as aerodynamic performance (Norberg \& Rayner, 1987; Arevalo et al., 2020), echolocation (Barclay \& Brigham, 1991; Jones, 1999; López-Cuamatzi et al., 2020; Arevalo et al., 2020), basal metabolic rate (MacNab, 2003), biomechanical properties (Swartz \& Middleton, 2008), dietary habits (Norberg \& Fenton, 1988), foraging habitats (Muscarella \& Fleming, 2007) and other life history traits (Safi et al., 2013). Body measurements, therefore, can be a reliable proxy for general size, being informative regarding environmental changes and ecosystem functions as well (García-Morales et al., 2016; Castillo-Figueroa \& PérezTorres, 2018).
Body mass: related to morphometric structures including skull size (Aguirre et al., 2002), length of the digestive tract (Bonaccorso, 1979), biomechanics structures of postcranial skeleton (Swartz \& Middleton, 2008) and wings (Norberg \& Rayner, 1987). Body mass is also linked to other functions associated to wingbeat frequency (Jones, 1999; Norberg \& Norberg, 2012), pulse duration (Jones, 1999), peak frequency (Jones, 1999; Thiagavel et al., 2017; López-Cuamatzi et al., 2020), bite force (Aguirre et al., 2002), basal metabolic rate (Kleiber, 1947; Soriano et al., 2002), quantity, quality and time invested in food handling (Fleming, 1991; Gómez-Ortiz \& Moreno, 2017), hardness and size of the food (Aguirre et al., 2003), and niche partitioning (Willig et al., 2003). In frugivorous bats, 
body mass is positively related to foraging height (Rex et al., 2011), food transit time (Laska, 1990), and the consumption of large-sized and low-quality fruits (low concentration of sugars and proteins), with a longer time in handling, processing and intestinal transit (Fleming, 1991; Saldaña-Vázquez, 2014a). Large species are more likely to disperse heavier fruits (López \& Vaughan, 2004), colonize and dominate urban environments (Saldaña-Vázquez \& Schondube, 2016; Jung \& Threlfall, 2018) as well as other human-dominated landscapes (e.g., coffee plantations) (Frank et al., 2017), but are prone to be more vulnerable to habitat loss (Martínez-Ferreira et al., 2020) and fragmentation (Farneda et al., 2015). Body size also determines the foraging habitats of frugivorous bats (Muscarella \& Fleming, 2007); that is, small bats with low wing loading and low aspect ratio can potentially forage both in the understory and canopy of forests because of their greater maneuverability. Conversely, larger species with high wing loading and high aspect ratio are less maneuverable and tend to forage in the canopy (Norberg \& Rayner, 1987; Muscarella \& Fleming, 2007). It has been found that body mass is positively correlated with colony size, which is associated with lower individual predation risk and with certain morphological features such as the absence pelage markings (Santana et al., 2011b). Also, to some extent, body size seems to be positively related to home range in some fig-eating stenodermatines (Kalko et al., 1996).

Total length: this trait comprises the length from the tail, if any, to the head. Total length is associated to body size, developmental stage, and the amount of resources and energy required by bats (Gómez-Ortiz \& Moreno, 2017).

Forearm length: a reliable proxy for body size (Dietz et al., 2006; Safi et al., 2013; Thiagavel et al., 2017). In phyllostomid bats, forearm length is positively related to nose leaf length (Arita, 1990). Studies conducted in silvopastoral agricultural systems have shown an increase of forearm length because of the availability of food and roosting sites (Ballesteros-Correa, 2015; Castillo-Figueroa \& Pérez-Torres, 2018; Chacón-Pacheco \& BallesterosCorrea, 2019). This trait can be converted to a categorical variable, and the species may be classified in three groups, according to Muñoz (2001) as follows: small (<40 mm), medium ( $40 \mathrm{~mm}-60 \mathrm{~mm})$ and large (>60 mm). Maneuverability is also related to size; small bats are more likely to perform a better flight performance in highly cluttered habitats than large and fast-flying bats (Thollesson \& Norberg, 1991; Stockwell, 2001; Denzinger et al., 2016). Particularly, for insectivorous bats, forearm length is a significant predictor of peak frequency and wing morphology; that is, small species with low wing loadings and low aspect ratios tend to emit higher frequency calls, whereas large species with high wing loading and high aspect ratio are characterized by emit lower frequency signals (Norberg \& Rayner, 1987; Thiagavel et al., 2017; Núñez et al., 2019). It has been also found a positive correlation between forearm length and prey size (Houston et al., 2004). For stenodermatinae bats, species that use leaf tents as diurnal roosts display short forearm length than bats that use other type of roosts (Garbino \& Tavares, 2018).

\section{Wing complex}

Wings are the idiosyncratic structures that distinguish bats from other mammals (Camargo \& Oliveira, 2012; Castillo-Figueroa, 2018b). The development of this multivariate flight apparatus was paramount in bat adaptative radiation (Cooper \& Sears, 2013), allowing the colonization of several niches in their evolutionary history (Sears et al., 2006). As such, bat wings consist of modifications of forelimbs, characterized by a membrane of skin, known as dactylopatagia, which is stretched between elongated digits (digits II-V) (Wang et al., 2010). Besides the explicit relationship of wings with locomotion and flight performance (Norberg \& Rayner, 1987), this structure plays a major role in thermoregulation (Makanya \& Mortola, 2007), food handling (Vandoros \& Dumont, 2004), habitat use (Marinello \& Bernard, 2014; Castillo-Figueroa, 2020a), foraging mode (Marinello \& Bernard, 2014), vertical stratification (Olaya-Rodríguez et al., 2019), assistance in delivery of pups and male-male aggression (Swartz \& Middleton, 2008).

Length of the third digit: measure of hand-wing length. A high ratio between third digit length and forearm length indicates long wings and thereby fast flights and low energy expenditure (Dietz et al., 2006; CastilloFigueroa, 2020a). Lower values of length of the third digit in relation to length of the fifth digit indicate short wings adapted to a slow flight in narrow habitats (Dietz et al., 2006; Castillo-Figueroa \& Pérez-Torres, 2018). Altogether with forearm length and length of the fifth digit, this trait is a good proxy of wing morphology (Findley et al., 1972).

Length of the fifth digit: measure of the wing width. A high ratio between the length of the fifth digit and forearm length indicates wide wings with high maneuverability and hovering capacity (Dietz et al., 2006; Castillo-Figueroa, 2020a), slow flights and low wing loading (Lisón, 2012). A high ratio between the length of the third digit and the fifth digit indicates long wings, adapted to fast flight in uncluttered habitats and open areas (Dietz et al., 2006). This measure together with forearm length and length of the fifth digit is a good proxy of the wing morphology (Findley et al., 1972).

Wing loading: defined as the relationship between weight and wing area, wing loading reflects the flight speed and the ability to load items during the flight (Giannini \& Brenes, 2001). Small bats have low wing loadings (Norberg \& Rayner, 1987; Thollesson \& Norberg, 1991), whereas large bats that carry heavier fruits, preys and pups (in the case of reproductive females), usually have higher wing loadings (Norberg \& Rayner, 1987; Thollesson \& Norberg, 1991). This trait is positively related to higher heart mass, thus compensating for the energy expenditure generated by rapid flights (RodríguezDurán \& Padilla-Rodríguez, 2008). Bats with high wing 
loadings are suitable to better exploit uncluttered habitats with few dodges and obstacles, whereas in highly cluttered areas bats with low wing loadings are more likely to use efficiently these habitats (Norberg \& Rayner, 1987; Kalcounis \& Brigham, 1995; Marinello \& Bernard, 2014). Due to this, bats with high wing loading are more tolerant to urban and suburban areas because this trait favor high-speed flight at low-energy cost, allowing for the exportation of open environments which are quite common in cities (Jung \& Threlfall, 2018; Ramírez-Mejía et al., 2020). Wing loading is also related to echolocation traits. Bats with high wing loading and high aspect ratio are likely to produce long-duration signals and low frequency calls (Norberg \& Rayner, 1987; Jones, 1999). By contrast, bats with low aspect ratio and low wing loading are more likely to generate echoes characterized by high frequency and short-duration signals (Norberg \& Rayner, 1987; Jones, 1999). High wing loading in frugivorous bats also indicates higher flexibility in the use of space and a higher ability to move between fragments (Farneda et al., 2015; Frank et al., 2017), contrary to species with low wing loading which are prone to be negatively affected by habitat loss and fragmentation (Frank et al., 2017; Martínez-Ferreira et al., 2020).

Aspect ratio: reflects the wing width in relation to the body (wing narrowness) and is positively related to flight efficiency and flight speed (Norberg \& Rayner, 1987; Thollesson \& Norberg, 1991) and inversely related to flight energy expenditure (Giannini \& Brenes, 2001). Species with a higher aspect ratio have constant and high-speed flights at low-energy costs generally in upper strata (Blood \& McFarlane, 1988; Saunders \& Barclay, 1992), as well as long commuting flights (Giannini \& Brenes, 2001). By contrast, species with lower values in aspect ratio have slower but more maneuverable flights generally in low strata (Blood \& McFarlane, 1988; Thollesson \& Norberg, 1991; Saunders \& Barclay, 1992). Species that forage in open and uncluttered areas, like many aerial insectivores, have high aspect ratios, whereas species typical of cluttered spaces such as forest interiors have low aspect ratios (Norberg \& Rayner, 1987). Bats with high aspect ratio and high wing loading tend to produce echolocation calls of low frequency and long duration, whereas bats that display low aspect ratio and low wing loading are more likely to emit calls of high frequency and short duration (Norberg \& Rayner, 1987; Jones, 1999). In frugivorous bats, low aspect ratio explains higher diversity of fruits consumed because of slow and highly maneuverability flights that allow to forage in all forest strata (Laurindo et al., 2020). It has been found that bats with low aspect ratio tend to be negatively affected by habitat loss and fragmentation (Martínez-Ferreira et al., 2020), whereas bats with high aspect ratio seems to be more tolerant to human-made landscapes such as urban and suburban areas, since they are able to exploit open environments (Jung \& Threlfall, 2018).

Tip shape index: wingtip shape estimates wingtip geometry (Norberg \& Rayner, 1987) and indicates maneu- verability within dense vegetation (Findley \& Wilson, 1982). Tip shape varies depending on the forest strata used by particular species, being higher in understory vegetation (Olaya-Rodríguez et al., 2019). According to this index, wingtips can be triangular $(I=0)$, rounded $(I>0)$, or pointed $(I<0)$ (Norberg \& Rayner, 1987; Norberg, 1990, 1994). Bats with large tip shape index (rounded) perform low flight speed, whereas bats that display small tip shape (pointed) can make flights with high roll acceleration (Thollesson \& Norberg, 1991). Tip shape index is also related to echolocation traits. Pointed wingtips are related to calls with low frequency and long duration, whereas rounded wingtips are associated to echoes characterized by high frequency and short duration (Norberg \& Rayner, 1987). In the case of insectivorous bats, rounded wings are related to generalist diet because of higher maneuverability that allow to exploit a high diversity of habitats and prey items, whereas pointed wings are related to specialist diet as a consequence of less maneuverable flights that restrict bat foraging to a narrow range of habitats and preys (Magalhães de Oliveira et al., 2020).

Wing span: measure showing the amplitude of the extended wings over the long axis of the body (Thollesson \& Norberg, 1991). Higher flight speed is common in bats that present shorter wing span and thinner body, whereas lower flight speed is common in bats that display longer wing span and large wing area (Thollesson \& Norberg, 1991). Similar to birds, this trait can be related to size, dispersion capacity and flight performance (Claramunt et al., 2012).

\section{Pollex complex}

The pollex (thumb) is the only structure of the forelimbs that has not been drastically modified for powered flight in bats (Granatosky, 2018). However, the pollex is very important in other functions such as terrestrial quadrupedal locomotion (Granatosky, 2018), food manipulation, perching and climbing over several types of substrates (Walldorf \& Mehlhorn, 2013). The length of the pollex can vary from being vestigial (Furipteridae), very small (Thyropteridae) to very developed (e.g., Desmodus rotundus). This body complex is probably, one of the less investigated in terms of ecological variations.

Length of the pollex without claw: related to food handling and locomotion. This trait is not integrated into the membrane and therefore has a function to grip, hold and scale (Walldorf \& Mehlhorn, 2013). The pollex varies considerably in size across guilds. Species that use the pollex to manipulate food, move or perch, display longer pollex length (Myers et al., 2016). In the case of blood-eating bats and particularly in Desmodus rotundus, longer pollex allows them to propel themselves from the ground to fly.

Length of the pollex with claw: related to food handling, including fruits (Uieda \& Vasconcellos-Neto, 1984) leaves (Pereira et al., 2017), and flowers (Vieira \& Carvalho- 
Okano, 1996; Tschapka, 2003; Sazima et al., 2003). Claws are also useful in climbing ability and defend from other bats (Myers et al., 2016).

\section{Hindlimbs complex}

Depending on the guild, the legs can be involved in key roles including prey capture (Fish et al., 1991), walking on the ground (Dietz, 1973), and food handling (Vandoros \& Dumont, 2004). The claws have a key function saving energy expenditure by perching with the tendon locking mechanism in roosting sites (Quinn \& Baumel, 1993).

Length of the foot without claw: related to the perching behavior, the capture of some preys and locomotion. The foots are useful in food-handling behaviors and are related to the type of suspension during food consumption (Vandoros \& Dumont, 2004).

Length of the foot with claw: related to the absolute drag force (air resistance) and the type of prey consumed (Fish et al., 1991). Higher values of the length of the foot with claw generate more absolute drag force but allow the capture of larger preys such as fishes and other vertebrates. Piscivorous bats have large foots, long and sharp claws (Denzinger et al., 2016) that can rotate 180 degrees to hook the slippery fishes they catch from the water (Fish et al., 1991). In nectarivorous bats that rely on landing on the flowers/inflorescences as foraging strategy, claws are useful in resource exploitation of flowers (Vieira \& Carvalho-Okano, 1996; Tschapka, 2003; Sazima et al., 2003). Large claws also are used in the manipulation of fruits (Uieda \& Vasconcellos-Neto, 1984) and preys (Fish et al., 1991).

Length of the tibia: measurement related to size (Swartz \& Middleton, 2008; Giannini et al., 2012). This trait has been poorly studied, but it is likely related to moving on surfaces such as foliage, soil, woods, among others. In bats with developed uropatagium, the width and maneuverability of this membrane is related to the length of the tibia.

Length of calcaneus: process that articulates with the posterolateral surface of the proximal region of the calcaneus (tarsal bone) (Adams \& Thibault, 1999). The calcaneus helps the uropatagium to change its curvature giving rigidity and flexibility simultaneously, thus being important in the aerodynamics of the flight by avoiding wind resistance, and improving maneuverability and hovering (Adams \& Thibault, 1999). In the case of insectivorous species, the calcaneus has a key role in prey capture, as it helps to stretch the uropatagium to catch insects and take them to the mouth (Webster \& Griffin, 1962).

\section{Head complex}

The head integrates the bulk of sensory functions in bats. Particularly, New World bats have a broad spectrum of morphological adaptations in the olfaction, which in some species are important for detecting resources such as ripe fruits (Mikich et al., 2003; Bianconi et al., 2007) insects (Hurtado et al., 2015), shelter and mates (Brokaw \& Smotherman, 2020). Indeed, external nasal morphology is strongly related to diet and foraging ecology (Brokaw \& Smotherman, 2020). Echolocation is a key feature for bats to detect and track preys and avoid obstacles as well. By doing so, the external ears receive the echoes of the environment and the tragus filters this information for localizing auditory targets (Chiu \& Moss, 2007). Thus, ear and nose traits are key to the acquisition of food, spatial orientation, and intraspecific and interspecific communication.

Length of the external ear: main structure of the acoustic system of bats that maximize the distance in which they can receive sound signals. This trait allows to locate potential preys, members of the same species (Balcombe \& Fenton, 1988), and detect predators (Fenton, 1980). Larger ears contribute to detect low auditory threshold of ultrasonic uptake, amplify incoming soundwaves from its surrounding, and improve the sensitivity of echolocation and directionality (Obrist et al., 1993; Huihua et al., 2003; Håkansson et al., 2017). Large ears may also hamper aerodynamic performance as they generate wind resistance during the flight (Gardiner et al., 2011a), precluding high-speed aerial acrobatics (Razak, 2018). During slow flights, however, large ears contribute to lift generation (Håkansson et al., 2017). Importantly, ear size is also related to foraging strategy and foraging habitats; that is, gleaning bats with large ears use them for passive listening and detecting preys, whereas bats with small ears usually fly faster in uncluttered habitats (Norberg \& Rayner, 1987; Gardiner et al., 2011a; Håkansson et al., 2017). Therefore, length of the ear size is associated to the composition of preys consumed, which may affect the ability of each species to regulate particular group of arthropods.

Length of tragus: this structure is a skin flap located lateral to the ear canal that is likely to affect the incoming acoustic signal, but also may generate spectral cues for vertical sound localization (Chiu \& Moss, 2007). The tragus has a functional contribution to the directivity patterns (Müller, 2004), and to elevation-dependent spectral cues which enable successful prey capture performance (Chiu \& Moss, 2007). The degree of inclination aids in detecting and processing acoustic signals (Müller, 2004). For gleaning animalivores, the tragus is more developed, providing gain for frequencies $(10-20 \mathrm{kHz})$ to capture preys more efficiently (Müller, 2004; Razak, 2018).

Length of nose leaf: typical structure of phyllostomid bats. This trait is mainly related to nose-emitted echolocation (King et al., 2013), and the length of the nasal spear correlates with the length of the forearm (Arita, 1990). Larger leaf-nose can be potentially associated with an increased ability to direct sound during echolocation in the vertical plane, allowing thus a more precise 
detection of food items in the dense foliage such as insects, fruits, and nectar (Martínez-Ferreira et al., 2020). This because a more developed leaf-nose favor a higher directionality of sonar beam, which gives two principal advantages to the species by, firstly, reducing the echoes from the periphery of the bat, minimizing thus the information that should be processed to detect objects and, secondly, enhancing the detection range by focusing the sound energy into an specific target (MartínezFerreira et al., 2020). Species that use hearing to locate roost or food have more developed nose leaf spears as is the case of species of Phyllostominae (Arita, 1990) and Lonchorhininae subfamilies (Brokaw \& Smotherman, 2020). Conversely, species that use vision or smell to locate the food, do not have large nose leaves, as is the case of Desmodontinae species (Arita, 1990). Secondary sexual dimorphism has been found in this structure in Phyllostominae bats (Hurtado et al., 2015), probably because females forage more intensely during pregnancy and breastfeeding, so they have developed significantly larger nose leaves than males to improve their foraging efficiency (Hurtado et al., 2015). In response to environmental conditions, leaf nose manipulation modulates the shape of the sound beam by adjusting the directionality (Martínez-Ferreira et al., 2020). For example, in structurally complex vegetation the leaf nose can modify frequency and intensity of the emitted sound, thus adjusting the search volume and the perception of vegetation structure, which ease the navigation in clutter habitats (Arita, 1990). In this sense, forest loss affect negatively species with large leaf-nose that forage in the dense foliage (Martínez-Ferreira et al., 2020).

Inner nostril width ratio: reflects the separation between receptors in bats (nostrils). Considering that the maximum separation of the nostrils is restricted by the cranial width (Stoddart, 1979), lower values of the inner nostril width ratio indicate wider nostrils and higher values entails narrow nostrils (Brokaw \& Smotherman, 2020). Wider separation between nostrils increase the effective area and the ability to detect different chemical signals from the environment (Stoddart, 1979). Diet, foraging habitat, foraging strategy, and echolocation are related to nostril separation (Brokaw \& Smotherman, 2020). Insectivorous bats that use uncluttered habitats, exhibit aerial foraging, and employ the oral mode of echolocation, show lower inner nostril width ratio (Brokaw \& Smotherman, 2020).

\section{Tail complex}

Although the structures of forelimb are mainly responsible for flight performance, the structures that support the tail membrane (uropatagium) are important for aerial locomotion, especially in maneuverability and thrust during horizontal takeoffs (Gardiner et al., 2011b; Adams et al., 2012). Moreover, uropatagium performs a key role in prey capture for insectivorous bats (Webster \& Griffin, 1962; Saunders \& Barclay, 1992; Kalko, 1995), carrying pups during the reproductive season (Adams \&
Thibault, 1999), and in thermoregulation through blood perfusion (Reeder \& Cowles, 1951).

Tail length: the tail and the surrounding membrane (uropatagium) are involved in flight performance by providing greater maneuverability (Gardiner et al., 2011b). These structures also provide thrust and horizontal displacement during the flight (Adams et al., 2012). Species with tails and larger uropatagia have better flight control (Gardiner et al., 2011b).

Uropatagium area: as a membrane structure, the uropatagium is an aerodynamic surface related to wing loading and should be included in flight performance assessments (Marinello \& Bernard, 2014). Larger uropatagium improves flight agility (Gardiner et al., 2011a, 2011b; Adams et al., 2012) and prey capture (Kalko, 1995). Species that consume evasive flying preys, such as moths, have a larger uropatagium (Saunders \& Barclay, 1992). Similarly, other bat guilds including piscivores and animalivores also have a large uropatagium area (Marinello \& Bernard, 2014). The uropatagium is also useful when carrying pups during the reproductive season and its manipulation is largely controlled by the calcaneus (Adams \& Thibault, 1999). Also, it has been proposed that nectar-eating bats uropatagium serves to transport pollen from one flower to another (Aguilar-Rodríguez et al., 2019).

\section{Life History Traits}

\section{Reproductive dimension}

Bats have a diversity of mating systems and reproductive strategies in response to environmental conditions (Crichton \& Krutzsch, 2000). Many of the reproductive traits are heavily determined by the distribution of food resources through time and space as well as ambient temperature (McGuire \& Boyle, 2013; Saldaña-Vázquez et al., 2020). In the Neotropics, reproductive patterns of many species can be synchronized with rainy seasons (Mello et al., 2004; Kunz et al., 2009), due to the increase of resources, mainly fruits and insects (Altringham, 2011). Nonetheless, with some exceptions, reproductive traits are poorly investigated in New World bats and the effects of habitat perturbation on reproduction are still unknown.

Litters per year: reflects reproductive output (Barclay \& Harder, 2003), availability and demand of trophic and spatial resources (Gómez-Ortiz \& Moreno, 2017). Bats tend to employ different reproductive strategies to produce offspring in favorable environments during specific times of the year (Fleming et al., 1972; Mello et al., 2004). For example, there is a correspondence between fruit abundance and arthropod biomass with rainfall, thus influencing reproductive timing for frugivorous and insectivorous bats, respectively (Crichton \& Krutzsch, 2000). It is important to highlight, however, that food availability rather than climatic factors underlies the timing of repro- 
ductive events in Neotropical bats (Crichton \& Krutzsch, 2000).

Litter size: related to bat fecundity (Barclay \& Harder, 2003). Litter size is influenced by several characteristics such as maternal body mass, pup mass and food intake (Speakman, 2008). In the case of insectivorous bats, dietary characteristics including the capacity to obtain calcium may constrain litter size (Barclay, 1994).

Gestation duration: reflects the demand of trophic and spatial resources (Gómez-Ortiz \& Moreno, 2017). The length of the pregnancy is a key period in bat reproduction (Crichton \& Krutzsch, 2000), which is influenced by availability of food, and environmental factors. Bats with long gestation periods are unable to react faster to shortterm environmental fluctuations, thus their reproduction strategy lies into predictable seasonal changes to maximize reproductive success (Crichton \& Krutzsch, 2000).

Lactation duration: this is the most energetically costly period (Speakman, 2008), in which bats increase the consumption of food during the early weeks of lactation to milk production and export (Kunz et al., 1995). Therefore, food availability is a key factor in determining the ability of females to obtain nutrients for reproduction (GómezOrtiz \& Moreno, 2017). Bats display a correspondence between lactation, or at least a part of it, and the peak of food availability (Crichton \& Krutzsch, 2000).

Reproductive status: related to fertility and timing of pregnancy (Stukenholtz et al., 2018) and can be influenced by environmental conditions (Vela-Vargas et al., 2016). Rather than temperature cycles (Crichton \& Krutzsch, 2000), rainfall seasonality may be the critical factor in Neotropical bat reproduction by influencing either directly reproductive activity or indirectly the availability of food resources (Mello et al., 2004; Montiel et al., 2011). During oestral cycle, hormone concentrations, mainly progesterone and estradiol, determine reproductive status in bats (Stukenholtz et al., 2018). Based on the monitoring of the reproductive status of males and females, four basic reproductive patterns of Neotropical bats can be distinguished: (1) reproduction all the year (e.g., Desmodontinae), (2) a long reproductive period with a short period of reproductive inactivity (e.g., Vespertilionidae) (3) bimodal seasonal polyoesstry defined by two reproductive peaks during the year (e.g., frugivorous from Phyllostomidae) and, (4) seasonal monoestry characterized by a single reproductive period during the year (e.g., Noctilionidae) (Fleming et al., 1972; Mello et al., 2004).

Sexual maturity age: the more time needed to reach adult age, the more demand for trophic and spatial resources (Gómez-Ortiz \& Moreno, 2017). This trait is also related to demography. Thus, generalist bats that become adults in a short time (e.g., four months) are more likely to have a higher abundance of adults in bat colonies (Mello \& Fernandes, 2000).
Mating systems: related to reproductive success, the protection of the offspring and the demand for trophic and spatial resources (Gómez-Ortiz \& Moreno, 2017). Mating systems are a consequence of bat that live in groups, where all the possible combinations to find a mate during reproduction are included (Davies et al., 2012). These systems entail intraspecific interactions where antagonistic reactions can occur in both sexes (i.e., sexual conflicts) (Davies et al., 2012). More broadly, mating systems can be classified into monogamic when male mates with only one female and the parental investment is the same for both sexes or polygamic when different combination between males and females can occur during breeding season (i.e., polyandria, polygyny, promiscuity). Species such as Vampyrum spectrum are monogamous, Carollia perspicillata, Artibeus lituratus and the bulk of the bats are polygynous, and Eptesicus fuscus are promiscuous (Altringham, 2011).

\section{Physiological dimension}

Physiological traits are among the most important in terms of the relationships with ecosystem processes. The way in which bats obtain the maximum amount of energy has remarkable effects on the interaction with their environment (Ayala-Berdon et al., 2013). Due to the experimental difficulties of their measurements but also the key information provided, these measurements are considered as "hard traits" (sensu Hodgson et al., 1999). Bat ecology is constrained by different environmental factors that encompass mean atmospheric temperature and humidity (McCain, 2007), as well as the availability of food resources (Montiel et al., 2011). Hence, several adaptations in physiological functions including echolocation, digestion, flight, thermoregulation and movement have been accomplished in the natural history of this mammal group.

Digestive capacity: directly related to diet diversity (Saldaña-Vázquez et al., 2015). In nectarivorous bats, rates of hexose assimilation as well as affinity of sucrase for its substrate affect the food quantity that an individual is capable to digest (Ayala-Berdon et al., 2013). Bats with higher digestive capacities can maintain a constant nutrient intake independently of diet quality (Ayala-Berdon \& Schondube, 2011; Saldaña-Vázquez \& Schondube, 2013). Also, high digestive capacity of bats to acquire and store energy from food intake can confer the ability to survive at montane and cold environments efficiently (Ayala-Berdon et al., 2013; Cruzblanca-Castro et al., 2018; Ortega-García et al., 2020). This means that physiological capacities to process energy are likely to influence spatial distribution of bats (Ayala-Berdon et al., 2013; Cruzblanca-Castro et al., 2018).

Gut size: gut plays a central role in diet diversity, especially in frugivorous bats (Saldaña-Vázquez et al., 2015). Larger gut size increases energy intake in low-quality food items (Karasov et al., 2011; Cruzblanca-Castro et al., 2018), enabling their digestion and potential germi- 
nation of pioneer plants (Saldaña-Vázquez, 2014a), but also may reduce viability of other seed species (Traveset, 1998). By contrast, shorter gut size contains a greater amount of lymph in the tissues which represents rapid assimilation of nutrients (Oliveira \& Lemes, 2010). Gut size may also limit food intake volume in nectarivorous bats (Ayala-Berdon \& Schondube, 2011).

Gut retention time of seeds: the time that seeds remain in the gut of an animal can prompt heavily effects for plant reproduction (Traveset, 1998). Retention of seeds may influence plant fitness through dispersal distance and gene flow (Murray et al., 1994; Shilton et al., 1999), recruitment of new individuals to plant populations (Schupp et al., 2010), and the seed germination (Baldwin \& Whitehead, 2015); therefore, the role of this trait may be pivotal in effective seed dispersal. Optimum retention time enables seed scarification (Jacomassa \& Pizo, 2010) and decreases minimum imbibition time, thus increasing germination probability of seeds, especially in dry ecosystems (Naranjo et al., 2003). Nevertheless, depending on the ecological context (the seeds, the dispersers, and environments), longer gut retention time can enhance seed germination (cleaning the pulp and with seed scarification) or, conversely, can reduce seed viability (damaging the seed with the acid environment of the gut) (Traveset, 1998). Overall, Neotropical bats present shorter food transit times, usually less than $1 \mathrm{~h}$ (Fleming, 1988; Baldwin \& Whitehead, 2015), which may be the best strategy to maximize energy gain in frugivorous bats, when eating a low-quality diet (Laska, 1990). Some studies have shown that gut retention time in bats can increase germination success but does not influence germination speed (Baldwin \& Whitehead, 2015). It is important to highlight that gut retention time is not only determined by intrinsic morphological and physiological features of the disperser animal, but also by extrinsic factors related to the food ingested such as nutrient composition, secondary compounds, consistency, mass, hardness and amount ingested (Laska, 1990; Cipollini \& Levey, 1997; Traveset, 1998; Baldwin \& Whitehead, 2015).

Type of lingual papillae: lingual physiology can be useful in elucidating dietary preferences and evolutionary patterns of feeding habits (Gregorin, 2003). Variations in papillae shape and distribution on the tongue are related to the way of capturing prey, the ingestion, and the diet (Pastor et al., 1993). For instance, in frugivorous bats that are not able to swallow big fruits, they can absorb the juice and avoid the fiber by using the mechanical and gustatory papillae (Gunawan et al., 2019), whereas nectivorous bats can perform nectar extraction by using a tongue with hair-like papillae or tongues with lateral grooves (Fleming et al., 2009; Tschapka et al., 2015; Lacher et al., 2019). The different types of lingual papillae may also vary at intra-specific level and between habitats or geographical locations (Gunawan et al., 2019).

Metabolic rate: related to the demand for trophic resources, energy expenditure (Gómez-Ortiz \& Moreno,
2017) and body mass (Kleiber, 1947; Soriano et al., 2002; MacNab, 2003). Variations in metabolic rate can also be related to feeding habits; that is, highest rates of metabolism are likely to be found on nectarivores, followed by frugivores, intermediate rates in frugivorous-insectivorous, and the lowest rates in hematophagous and insectivorous guilds (Soriano et al., 2002). Several environmental factors can affect metabolic efficiency such as rain through increasing the energy cost in bat flight (Voigt et al., 2011), ambient temperature via thermoregulation at lower and higher temperatures, elevation in which phytophagous bats can increase metabolic rate with increasing altitude (Soriano et al., 2002), and food quality that affect food volumetric ingestion and therefore energy intake (Ortega-García et al., 2020).

Body temperature: stress can elicit changes in body temperature (Muise et al., 2018; Ortega-García et al., 2020). Increasing rapidly body temperature may be critical to escape predators while roosting during day (Muise et al., 2018). The reduction of metabolic rate is related to a subsequent decreasing in heart rate and body temperature, which is strongly related to ambient temperature (O'Mara et al., 2017). For example, nights with rains, high winds and low ambient temperatures increase the use of torpor as a consequence of less energy intake (Klug \& Barclay, 2013; Ortega-García et al., 2020). Other factors such as poor foraging condition may increase the use of torpor, and reproduction (e.g., lactation and early development) may influence the thermoregulatory strategies employed by bats to control body temperature (Klug \& Barclay, 2013). Body mass is also related to body temperature given that large bats can better regulate their temperature than small bats regardless the guild (Soriano et al., 2002).

\section{Behavioral dimension}

Behavioral traits in New World bats are poorly known, mainly because of their cryptic lifestyles. Behavioral information is the cornerstone for many essential aspects of bats such as demography, ecological constraints, intraand interspecific interactions (Kerth, 2008). Moreover, behavioral changes are useful indicators of human-made habitat modification, as they may be an appropriate measure of sensitivity to disturbances other than traditional measures of species richness or abundance (Presley et al., 2009; Montaño-Centellas et al., 2015).

Migration: migration events during the reproductive season are necessary for some bats. Females' migrations to warmer sites improve prenatal development, thus enhancing breeding success (Saldaña-Vázquez et al., 2020). During migration bats flight over long distances and thereby this trait is linked to the demand for trophic and spatial resources, torpor, lethargy and temporary segregation (Esbérard et al., 2011; Gómez-Ortiz \& Moreno, 2017). Furthermore, altitudinal migration over shorter distances can be performed by bats because of seasonal variation in food resources across elevational gradient 
(McGuire \& Boyle, 2013), but also to find appropriate sites for breeding (Saldaña-Vázquez et al., 2020). This altitudinal movement may constitute an important factor affecting bat interactions with plant species they disperse and/ or pollinate (Saldaña-Vázquez et al., 2020), or insects they prey at different periods thought the year.

Sociality: bat aggregation may reduce energetic expenditure due to thermoregulatory demands in lactating mothers and juveniles (Agosta, 2002; Klug \& Barclay, 2013). Ecological factors such as roost or shelter limitation could forces bats to aggregate, even in contexts where group living is detrimental (Kerth, 2008). Moreover, physiological demands, demographic predispositions including philopatry, longevity and overlapping generations influence sociality in bats (Kerth, 2008). Depending on whether bats forage in a group or solitary could influence individuals' movement paths and spatial patterns of seed rain.

Foraging strategy: the way to capture the food allows species to take advantage of habitat heterogeneity and generate a higher resource partition in ecosystems (Patterson et al., 2003). It has been suggested that the more forage strategies, the more resources and habitats can be used by bats, which may be linked to a greater number of ecological processes (Mora-Fernández et al., 2013). Foraging strategy is related to diet; for example, insectivorous bats obtain their food primarily as aerial foragers but can also present a gleaning behavior; carnivorous, omnivorous and hematophagous bats consume some animals or parts of them (e.g., blood) that are captured in the foliage or some surface by employing different senses to locate their food (Kalko et al., 2008). Frugivorous bats can be canopy or understory since vertical stratification is associated to resource allocation because in each of these strategies there are differences in the quantity and quality of fruits they consume (Bonaccorso, 1979; Soriano, 2000). Also, foraging strategy in frugivorous bats are related to displacements performed per night to obtain the fruits and in the associations with the fruiting patterns of the plants (Big bang for canopy bats or Steady state for understory bats) (Bonaccorso, 1979; Soriano, 2000). Foraging strategy is also related to foraging habitat, since uncluttered areas (and in some cases background) are suitable places for aerial foragers, whereas narrow habitats are suitable for bats that gather their food on the foliage (Kalko et al., 2008), in the canopy or at understory level (Bonaccorso, 1979; Soriano, 2000). In the case of nectarivorous bats, trap-lining foraging contributes to efficiency as pollen dispersers over long distances, promoting outcrossing in plants (Muchhala \& Thomson, 2010). These foraging strategies are likely to influence plants distribution patterns.

Activity pattern: bat activity represents an important niche dimension because indicates how species exploit the environment (Presley et al., 2009). The optimization of activity times is critical for the species survival (Di
Blanco et al., 2017), and the bulk of these temporal events are associated with predatory and anti-predatory strategies as well as temporary segregation (Thies et al., 2006; Gómez-Ortiz \& Moreno, 2017). Environmental factors such as rain (Voigt et al., 2011), humidity (Ferro-Muñoz et al., 2018) and temperature (Barclay, 1985; Verde, et al., 2018; Ferro-Muñoz et al., 2018) may influence energy expenditure by constraining foraging activity times. Bat activity patterns may also respond to local disturbance (Montaño-Centellas et al., 2015), habitat conversion (Presley et al., 2009), and availability to ripe fruit in the case of frugivorous (Thies et al., 2006). Other factors including moonlight intensity displays a negative relationship to bat activity, especially for those species that forages in open habitats such as water surfaces and forest canopy (Saldaña-Vázquez \& Munguía-Rosas, 2013).

\section{Trophic niche dimension}

New World bats, particularly from Phyllostomidae family, show a high diversity feeding habits as well as foraging strategies to obtain their food. According to optimal foraging theory (MacArthur \& Pianka, 1966; Schoener, 1971), an animal displays the best strategy to accomplish the maximum benefit with the lowest energetic cost. In line with this argument, Neotropical bats are under several ecosystem contexts in which many extrinsic and intrinsic factors influence the ability to exploit food and better maximize energetic gains (SaldañaVázquez, 2014a). The consequences of the interactions between bats and their food resources are reflected in ecosystem functions associated to seed dispersal, pollination, arthropod suppression, vertebrate control, and the regulation of pathogens and diseases (Kunz et al., 2011; Kasso \& Balakrishnan, 2013; Lacher et al., 2019; Castillo-Figueroa, 2020b).

Feeding guild: reflects the strategy of resource partitioning within bat assemblages (Wilson, 1973; Giannini \& Kalko, 2004). Diet is related to processes such as seed dispersal (frugivorous), pollination (nectarivorous), pest and disease control (insectivorous) (Mora-Fernández et al., 2013). Dietary characteristics are related to several morphometric traits of the skull (Santana et al., 2012), jaw (Monteiro \& Nogueira, 2010) teeth (Santana et al., 2011a), wing morphology (Marinello \& Bernard, 2014), inner nostril width ratio (Brokaw \& Smotherman, 2020), and bite force (Nogueira et al., 2009) This trait is also a predictor of vulnerability to fragmentation (Farneda et al., 2015) and is related to species sensitivity to environmental changes affecting food resources (Ramírez-Mejía et al., 2020).

Diet specialization: in frugivorous bats is related to intrinsic factors including foraging behavior, mouth morphology, bite force, digestive physiology (SaldañaVázquez, 2014a) and body size (Saldaña-Vásquez \& Schondube, 2013). Likewise, dietary specialization has shown relationships with extrinsic factors such as plant phenology (Thies \& Kalko, 2004), the physical characteristics of the fruit, the non-digestible material, secondary 
metabolites, nutrients, fruit energy (Saldaña-Vázquez, 2014a), latitude, altitude, and ecoregion (SaldañaVásquez \& Schondube, 2013). This trait is also a key factor that determines the structure of the bat assemblage (Saldaña-Vázquez, 2014a) and are likely related to floristic diversity and supply of resources where the species are found (Fleming, 1986; Loayza et al., 2006). Considering intraspecific characteristics, dietary specialization can differ between males and females (Alviz \& Pérez-Torres, 2020) and between reproductive stages (Bohlender et al., 2018). Interestingly, this trait is not related to habitat fragmentation (Meyer et al., 2008; Farneda et al., 2015), despite that this process isolates and reduces resources for many species (Pérez-Torres, 2004). Nonetheless, narrow dietary breath is related to extinction risk in insectivorous bats (Boyles \& Storm, 2007). Wing morphology seems to be related to dietary specialization. For example, frugivorous bats with low aspect ratio tend to have a high dietary breadth due to slow and highly maneuverability flights that enable to forage in all forest habitats (Laurindo et al., 2020). Similarly, for insectivorous bats, individuals with more rounded wings have a more generalist diet, whereas individuals with more triangular and pointed wings present specialized diets (Magalhães de Oliveira et al., 2020).

Bite force: reflects the performance of the whole organism and can be linked to the fitness (Anderson et al., 2008; Davis et al., 2010), because of its influence on the spectrum of available food and niche partitioning (Aguirre et al., 2003). Bite force is strongly correlated to body mass (Aguirre et al., 2002), food size and food hardness (Aguirre et al., 2003), limiting dietary selection in bats. Importantly, bite force is also related to size gap angle and bite point (Dumont \& Herrel, 2003; Santana, 2015), skull and mandibular shape (Nogueira et al., 2009), as well as temporalis muscle mass, temporalis fiber length and masseter muscle mass (Herrel et al., 2008).

\section{Spatial niche dimension}

Bats can occur in almost all the environments of the Neotropics, ranging from sea level to montane forests and paramos across different ecosystems with a diversity of vegetational physiognomies, habitat complexities, and landscapes characteristics (including man-made environments and structures). Accordingly, bats have developed different strategies, morphological adaptations and aerodynamic features to use the horizontal and vertical space. In doing so, bats can move genetic material (e.g., pollen or seeds) between sites, promoting plant reproduction (Quesada et al., 2003). Bats can also track their preys thought the space and time, being important as agents for the suppression of agricultural pests (McCracken et al., 2012).

Foraging habitat: related to echolocation conditions and foraging strategy (Schnitzler \& Kalko, 2001; Schnitzler et al., 2003; Denzinger \& Schnitzler, 2013; Denzinger et al., 2016). In uncluttered habitats, insectiv- orous bats generally have echolocation characterized by calls with low frequency and narrow band, adapted to detect insects over long distances (Kalko et al., 2008). High-frequency signals are emitted in edge areas that present a component used to detect flying insects and another component to detect oscillations (Kalko et al., 2008). In these habitats are also bats that forage water surfaces (Denzinger \& Schniltzler, 2013). In highly cluttered habitats, the waves emitted are short, broadband, multi-harmonic and often modulated (Kalko et al., 2008). In these habitats, it is difficult to distinguish the echoes coming from the food (fruits, nectar, insects, small vertebrates) from the echoes generated by the surrounding vegetation (Denzinger \& Schnitzler, 2013). To solve this, they can specialize in detecting insect flutter, by using passively foraging when using other senses (sit- and wait strategy), or employing actively foraging of conspicuous local resources, or even combining passive and active foraging which is common in phytophagous bats (frugivorous and nectarivorous) (Denzinger \& Schnitzler, 2013). Foraging habitat is also related to wing and ear morphology, thereby in cluttered habitats, the predominant ecoforms are wide and short wings (Kalko et al., 2008) with low wing loading and aspect ratio (Norberg \& Rayner, 1987), longer length of the fifth digit in proportion to the length of the third digit and forearm length (Dietz et al., 2006; Castillo-Figueroa, 2020a), allowing greater maneuverability and agility (Norberg \& Rayner, 1987). In these habitats, bats are likely to have large ears and slow flights for passive listening to detect prey, (Norberg \& Rayner, 1987; Gardiner et al., 2011a; Håkansson et al., 2017). By contrast, in uncluttered spaces, the predominant ecoforms are long wings (Kalko et al., 2008) with high wing loading and aspect ratio (Norberg \& Rayner, 1987), and smaller length of the fifth digit in proportion to the length of the third digit and forearm length (Dietz et al., 2006; Castillo-Figueroa, 2020a), thus enabling fastspeed flights (Norberg \& Rayner, 1987). To reduce drag and enhance aerodynamic performance, bats have small ears that enable fast flights over open habitats (Norberg \& Rayner, 1987; Gardiner et al., 2011a; Håkansson et al., 2017). In forest edges, the wings are wide and somewhat short to avoid obstacles and dodges like trunks, branches, shrubs and foliage (Kalko et al., 2008). Prior studies have shown that tolerance of insectivorous bats to urbanization is more likely to occur in species that forage in open and edge spaces as well as in bats with flexible roosting strategies (Jung \& Threlfall, 2018).

Vertical stratification: related to habitat specialization (Pereira et al., 2010; Farneda et al., 2015; Gregorin et al., 2017) and wing ecomorphology (Olaya-Rodríguez et al., 2019). In frugivorous bats, vertical stratification can occur depending on fruit-sized differences among forest strata, considering that fruit size is related to bat size (Kalko et al., 1996; Muscarella \& Fleming, 2007; Lacher et al., 2019). Thus, small species feed mainly on small fruits in the understory, whereas large species tend to consume large fruits in the canopy (Kalko et al., 1996; Rex et al., 2011). However, this is a flexible trait (Meyer et al., 2008; 
García-García, et al., 2014) that may not reflect the foraging height (Rex et al., 2011), but depending the functional group and ecological context, stratification can be a good predictor of vulnerability of species (Duchamp \& Swihart, 2008; Farneda et al., 2015).

Home range: related to connectivity of species between habitat patches (Bernard \& Fenton, 2003; Loayza $\&$ Loiselle, 2008). The ability to flight long distances over open areas affects the processes of seed dispersal, pollination, and arthropod control, respectively (GalindoGonzález, 1998; Bernard \& Fenton, 2003; Kalka \& Kalko, 2006; Mello et al., 2008). In frugivorous bats, seed dispersal over long distances reduces intraspecific competition and seed predation (Janzen, 1970; Muscarella \& Fleming, 2007), and promote seed deposition in suitable microsites enhancing germination (Heithaus \& Fleming, 1978; Galindo-González, 1998; Mello et al., 2008). In the case of nectarivores, pollen movement over short and long distances, and trap-lining foraging resulting in outcrossing pollination, thus increasing gene flow in plants (Muchhala, 2006; Fleming et al., 2009), especially in fragmented landscapes (Quesada et al., 2003). For insectivorous bats, some gleaners display high efficiency in exploitation of preys even on small forest patches where habitat suitability is very low (Kalko et al., 2008). To some extent, home range appear to be directly related to body size in fig-eating stenodermatines (Kalko et al., 1996).

Type of roost: related to skull morphology, body size, pelage patterns, social organization and group size (Kunz, 1982; Santana et al., 2011b; Garbino \& Tavares, 2018). Diurnal roosts are a fundamental resource for bats because, on one hand, they spend at least half of their lives in these sites (Kunz, 1982) and, on the other hand, roost environments allow species coexistence and are linked to morphological or behavioral adaptations of bats (Voss et al., 2016). The remarkable variety of diurnal refugia used by bats include caves, rock outcrops, termite nests, foliage, crevices and shallow grottoes, fallen trees, tree barks and vine tangles (Kalko et al., 1999; Sampedro et al., 2008; Voss et al., 2016). This is important because bats play a key role in nutrient cycling by fertilizing sites that are used as roosts (Castillo-Figueroa, 2020b), thus increasing, for instance, nitrogen content in the trees and soils (Voigt et al., 2015). The potential effect of bats in the increase of nutrients by defecating within and nearby the roost tree (nutrient hot spot hypothesis), remains to be explored in Neotropical bats (Pierson, 1998; Duchamp et al., 2010; Castillo-Figueroa, 2020b). Roosting ecology is also phylogenetically informative, and along with other traits, roost selection may explain morphological variation in bats; for example, species that use leaf tents are smaller than bats that use other type of roosts, and pelage markings such as white stripes of stenodermatines are related to foliage roosting (Garbino \& Tavares, 2018). In terms of community ecology, the availability and the type of roosts may play a major role in environmental filtering of bat species at a local or regional scale (Voss et al., 2016). For instance, tolerance to urbanization is more likely to occur in insectivorous bats with flexible roosting strategies and this could influence species composition in urban environments (Jung \& Threlfall, 2018).

\section{Echolocation dimension}

Echolocation is, probably, one of the most important traits of bats to perceive their environment. Bats can produce calls of extraordinary high frequencies ranging from $20 \mathrm{kHz}$ to $212 \mathrm{kHz}$ (Thiagavel et al., 2017). These tonal signals, emitted mainly in the larynx, can return in echoes that enable the detection, localization, and characterization of reflecting targets, including preys and obstacles in the habitat (Schnitzler et al., 2003). This allows bats to orient themselves spatially, recognize biotopes, and find their food (Neuweiler, 2000; Denzinger \& Schnitzer, 2013). Therefore, identifying echolocation signals is useful to study the interactions between bats and their environments (Neuweiler, 2000), especially for insectivores' guilds, which usually escape from traditional techniques such as mist-nets (Estrada-Villegas et al., 2010). Indeed, resource partitioning by echolocation is, arguably, a key factor to understand the structuring of bat communities (Houston et al., 2004).

Duration: related to the efficiency of prey-acquisition according to the habitats (Saldaña-Vázquez, 2014b). Shortduration signals may enable the detection of different prey sizes but is limited to short ranges by atmospheric attenuation, whereas long-duration signals reach distant preys but may limit availability of small preys (Houston et al., 2004). Accordingly, in uncluttered spaces bats can emit calls of longer duration, increasing the probability to record distant objects or preys, whereas in cluttered habitats the duration of the calls is shorter, enhancing the spatial orientation and prey detection in dense foliage (Jones \& Holderied, 2007; Barboza-Marquez et al., 2013; Denzinger \& Schnitzer, 2013). Pulse duration is related to body mass (Jones, 1999) and wing morphology (Norberg \& Rayner, 1987); that is, larger bats have high wing loading and high aspect ratio reflected in faster flights, thus allowing to search for distant preys (Norberg \& Rayner, 1987). In such circumstances, bats can increase pulse duration because echoes will return late from distant targets (Jones, 1999). Conversely, small and maneuverable bats with low wing loading and low aspect ratio are capable to detect a wide range of target sizes over nearby distances by emitting shorter pulses to avoid pulse-echo overlap (Jones, 1999; Houston et al., 2004).

Interval: similar to the duration, the interval of the call can be reduced while the bat is approaching the prey since its echolocation system does not allow to discern the overlap between the emitted signal and the echo that returns, either during or soon after call emission (Kalko, 1995; Jones \& Holderied, 2007; Saldaña-Vázquez, 2014b). In open habitats, where no objects can mask the echoes of the prey, bats can generate calls of longer intervals, improving the chances of detecting preys that are from far distances (Barclay, 1985). In dense habitats, 
intervals are short to improve aerial navigation and insect-acquisition in complex habitats (Barboza-Marquez et al., 2013; Denzinger \& Schnitzer, 2013).

Frequency: in echolocation, this is probably the most variable trait (Saldaña-Vázquez, 2014b). Broadly, low frequencies and long signals reduce the probability for detect small preys, whereas high frequencies in conjunction with short signals increase the capacity to detect large preys, but only in short distances (Barclay, 1985; Kalko, 1995; Houston et al., 2004; Jones \& Holderied, 2007). This because at high-frequency calls there is a high atmospheric attenuation, making these signals only operational over short ranges (Jones, 1999; Houston et al., 2004). Bats with larger ears can detect low frequency calls and improve directionality (Obrist et al., 1993; Huihua et al., 2003). Frequency is also related to size (Jones, 1999) and wing morphology (Norberg \& Rayner, 1987); smaller bats with low wing loading, low aspect ratio and rounded wingtips produce higher frequency signals to move in cluttered habitats, conversely, larger bats with high wing loading, high aspect ratio and pointed wingtips use lower frequency sounds to forage on uncluttered spaces (Jones, 1999; Thiagavel et al., 2017; Núñez et al., 2019; López-Cuamatzi et al., 2020).

Intensity: the variation of this trait is minute in comparison to the other call parameters (Saldaña-Vázquez, 2014b). Bats tend to emit intense tonal signals when hunting and can also adjust the sound level of search calls according to the distance of closest obstacles in their natural habitats (Surlykke \& Kalko, 2008). High intensity is found in bats that forage on uncluttered spaces due to the attenuation of the sound through space (Jones \& Holderied, 2007). However, low intensity calls, typical of sit- and wait foragers, can increase the efficiency in tracking preys since their tonal signs are not overlapping with the glints in insects' echoes (Holderied et al., 2010). Intensity is unrelated to body size, being that smaller species can emit both high and low intensity sounds (Saldaña-Vázquez, 2014b).
Harmonics: the use of harmonics enhance the resolution of preys and objects without modulation of the frequency (Holderied et al., 2010; Bates et al., 2011), allowing to exploit insect preys of different size (Jones \& Holderied, 2007). Bats that forage close to objects usually modulate the frequency of the calls by adding harmonics (Denzinger \& Schnitzer, 2013). Harmonics allow to discriminate clutter echoes from target echoes by sacrificing delay acuity to avoid masking effect (Bates et al., 2011).

\section{Application of the framework}

Historically, body size and wing morphology, e.g., body mass, wing loading and aspect ratio, have been employed to assess species performance and ecological correlations with several environmental characteristics (Cisneros et al., 2014; Farneda et al., 2015; Cisneros et al., 2015; Cisneros et al., 2016). In our review, we found 19 study cases using trait-based approach in Neotropical bats, and most of them have focused on response traits across human-dominated landscapes (Presley et al., 2017; Farneda et al., 2019; Ramírez-Mejía et al., 2020) and elevational gradients (Rodrigues Coelho et al., 2018; Mancini et al., 2019) as is shown in Table 2 and Fig. 2. It is clear enough that this framework is particularly useful for studying biodiversity patterns and species response across human-made landscapes in the Neotropics, as specific combinations of traits may predict the ecological structure of communities in urban or rural contexts (Jung \& Threlfall, 2018; Ramírez-Mejía et al., 2020).

However, effect traits have been largely neglected. To our knowledge, only one paper directly related traits to seed dispersal process through ecological network approach (Laurindo et al., 2020). Nonetheless, some physiological and behavioral studies related to foraging ecology have started to shed light on trait relations to ecological processes (Baldwin \& Whitehead, 2015; Ortega-García et al., 2020; Saldaña-Vázquez et al., 2020) as we mentioned above. We consider that these studies may be a point of reference for further investigations on effect traits in bats.

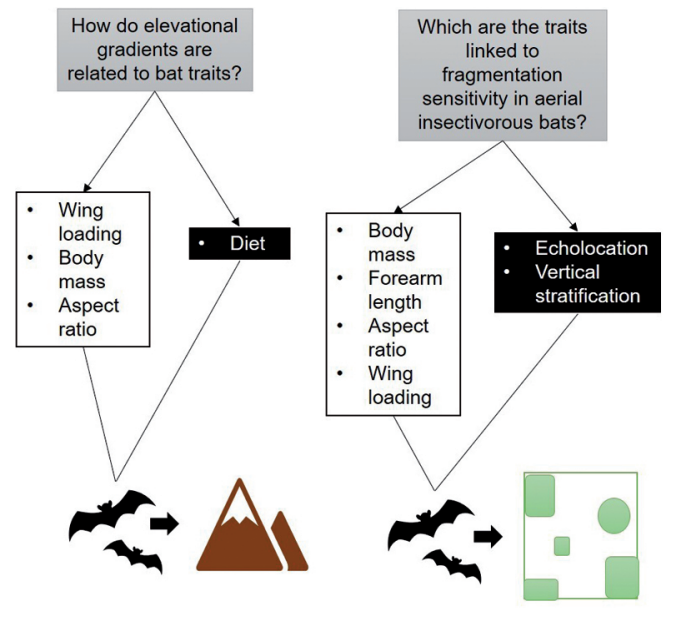

Mancini et al., 2019

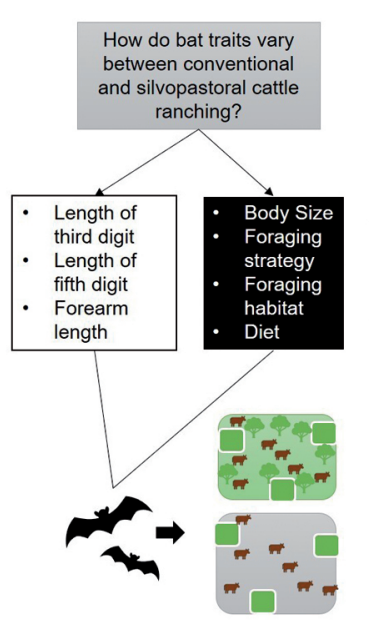

Castillo-Figueroa \& Pérez-Torres, 2018
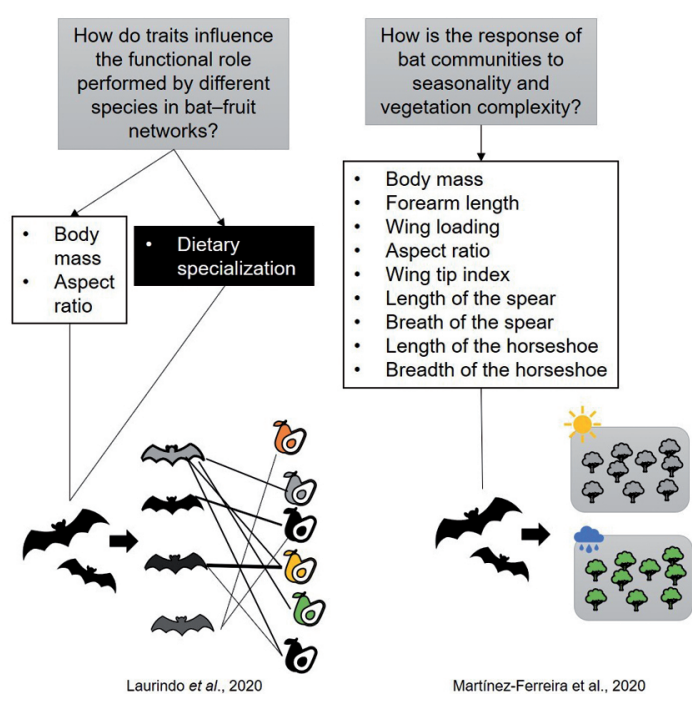

Figure 2. Study cases using trait-based approach in Neotropical bats. Life history traits in black boxes whereas morphological traits are depicted in white boxes. 
Table 2. Functional ecology studies of Neotropical bats using traits.

\begin{tabular}{|c|c|c|c|c|}
\hline Morphological Trait & Life history trait & Location & Application & Reference \\
\hline $\begin{array}{l}\text { Body size, forearm length, greatest length of skull, } \\
\text { condylobasal length, length of maxillary toothrow, breadth } \\
\text { across upper molars, width across post-orbital constriction, } \\
\text { breadth of braincase, wing loading, aspect ratio }\end{array}$ & $\begin{array}{l}\text { Diet, foraging location, foraging } \\
\text { strategy }\end{array}$ & Manu Biosphere Reserve, Perú & Response to elevational gradient & Cisneros et al., 2014 \\
\hline $\begin{array}{l}\text { Body size, forearm length, greatest length of skull, } \\
\text { condylobasal length, length of maxillary toothrow, breadth } \\
\text { across upper molars, width across post-orbital constriction, } \\
\text { Breadth of braincase, Wing loading, aspect ratio }\end{array}$ & $\begin{array}{l}\text { Diet, foraging location, foraging } \\
\text { strategy, roost type }\end{array}$ & $\begin{array}{l}\text { Caribbean lowlands in } \\
\text { northeastern Costa Rica }\end{array}$ & $\begin{array}{l}\text { Response to human-modified } \\
\text { landscapes }\end{array}$ & Cisneros et al., 2016 \\
\hline $\begin{array}{l}\text { Body size, forearm length, greatest length of skull, } \\
\text { condylobasal length, length of maxillary toothrow, breadth } \\
\text { across upper molars, width across post-orbital constriction, } \\
\text { breadth of braincase, wing loading, aspect ratio }\end{array}$ & $\begin{array}{l}\text { Diet, foraging location, foraging } \\
\text { strategy, roost type }\end{array}$ & $\begin{array}{l}\text { Caribbean lowlands of } \\
\text { northeastern Costa Rica }\end{array}$ & $\begin{array}{l}\text { Response to human-modified } \\
\text { landscapes }\end{array}$ & Cisneros et al., 2015 \\
\hline Body mass, wing aspect ratio, wing loading & $\begin{array}{l}\text { Trophic level, dietary } \\
\text { specialization, vertical } \\
\text { stratification, mobility }\end{array}$ & Manaus, Central Amazon, Brazil & $\begin{array}{l}\text { Response to habitat } \\
\text { fragmentation }\end{array}$ & Farneda et al., 2015 \\
\hline Body mass, forearm length, wing morphology & $\begin{array}{l}\text { Echolocation, Vertical } \\
\text { stratification }\end{array}$ & Manaus, Central Amazon, Brazil & $\begin{array}{l}\text { Response to habitat } \\
\text { fragmentation }\end{array}$ & Núñez et al., 2019 \\
\hline Body mass & Trophic level, diet, habitat breath & $\begin{array}{l}\text { Colombia, México, Bolivia, } \\
\text { Brazil, Costa Rica, Guatemala, } \\
\text { Nicaragua, Perú }\end{array}$ & Human-modified landscapes & Farneda et al., 2019 \\
\hline Body mass, wing loading & $\begin{array}{l}\text { Trophic level, dietary } \\
\text { specialization, vertical } \\
\text { stratification }\end{array}$ & Manaus, Central Amazon, Brazil & $\begin{array}{l}\text { Response to habitat } \\
\text { fragmentation }\end{array}$ & Farneda et al., 2018 \\
\hline Forearm length, aspect ratio, wing load and body mass & $\begin{array}{l}\text { foraging guild, main feeding } \\
\text { habits, main trophic level }\end{array}$ & Tocantins State, Central Brazil & $\begin{array}{l}\text { Response to human-modified } \\
\text { landscapes }\end{array}$ & Pereira et al., 2018 \\
\hline Body mass, wing aspect ratio, relative wing loading & $\begin{array}{l}\text { Trophic level, vertical foraging } \\
\text { area }\end{array}$ & Los Chimalapas, México & Habitat fragmentation & García-García et al., 2014 \\
\hline Body weight, forearm, wing loading, aspect ratio & Diet & Hidalgo, México & $\begin{array}{l}\text { Response to human-modified } \\
\text { landscapes }\end{array}$ & García-Morales et al., 2016 \\
\hline Body mass, aspect ratio, wing load & Type of food & $\begin{array}{l}\text { the Serra da Mantiqueira massif, } \\
\text { Minas Gerais and São Paulo, } \\
\text { Brazil }\end{array}$ & Response to elevational gradient & Mancini et al., 2019 \\
\hline $\begin{array}{l}\text { Weight (body mass), size (forearm), wing morphology (aspect } \\
\text { ratio and wing loading) }\end{array}$ & Dietary specialization & $\begin{array}{l}\text { North of the state of Paraná, } \\
\text { Brazil }\end{array}$ & $\begin{array}{l}\text { Response to human-modified } \\
\text { landscapes }\end{array}$ & Pereira et al., 2019 \\
\hline Weight, aspect ratio & $\begin{array}{l}\text { Feeding guild, type of shelter } \\
\text { used }\end{array}$ & Minas Gerais and Bahia, Brazil & Response to elevational gradient & Rodrigues Coelho et al., 2018 \\
\hline Length of third digit, length of fifth digit, forearm length & $\begin{array}{l}\text { Size, foraging strategy, foraging } \\
\text { habitat, diet }\end{array}$ & Córdoba, Colombia & $\begin{array}{l}\text { Response to human-modified } \\
\text { landscapes }\end{array}$ & $\begin{array}{l}\text { Castillo-Figueroa \& Pérez-Torres, } \\
2018\end{array}$ \\
\hline Body mass, wingspan, aspect ratio, wing loading & Trophic guild & Villavicencio, Colombia & $\begin{array}{l}\text { Response to human-modified } \\
\text { landscapes }\end{array}$ & Ramírez-Mejía et al., 2020 \\
\hline $\begin{array}{l}\text { Body mass, aspect ratio, greatest length, braincase and } \\
\text { zygomatic breadth }\end{array}$ & Degree of frugivory & México, Perú, Brazil, Guatemala & $\begin{array}{l}\text { Relation to seed dispersal } \\
\text { networks }\end{array}$ & Laurindo et al., 2020 \\
\hline $\begin{array}{l}\text { Aspect ratio, wing loading, forearm length, body mass, } \\
\text { breadth across molars, breadth of braincase, condylobasal } \\
\text { length, greatest length of skull, maxillary toothrow, } \\
\text { postorbital constriction }\end{array}$ & $\begin{array}{l}\text { Diet, foraging location, foraging } \\
\text { strategy }\end{array}$ & Sarapiquí, Costa Rica & $\begin{array}{l}\text { Response to human-modified } \\
\text { landscapes }\end{array}$ & Presley et al., 2017 \\
\hline $\begin{array}{l}\text { Weight, forearm lenght, wing loading, aspect ratio, wing tip } \\
\text { index, length of the spear, breadth of the spear, length of the } \\
\text { horseshoe, breadth of the horseshoe }\end{array}$ & Trophic guild & $\begin{array}{l}\text { Chamela-Cuixmala Biosphere } \\
\text { Reserve (CCBR), México }\end{array}$ & $\begin{array}{l}\text { Response to regenerating forests } \\
\text { and seasonality }\end{array}$ & Martínez-Ferreira et al., 2020 \\
\hline Body mass, wing loading, relative wing loading, aspecto ratio & $\begin{array}{l}\text { Diet, peak frequency, bandwidth, } \\
\text { call duration, roost duration }\end{array}$ & $\begin{array}{l}\text { Las Cruces Biological Station, } \\
\text { Costa Rica }\end{array}$ & $\begin{array}{l}\text { Response to human-modified } \\
\text { landscapes }\end{array}$ & Frank et al., 2017 \\
\hline
\end{tabular}

\section{DISCUSSION}

Intraspecific variation: as Neotropical bats have marked differences at the intraspecific level, including secondary sexual dimorphism (Camargo \& Oliveira, 2012; Stevens et al., 2013; Hurtado et al., 2015; CastilloFigueroa, 2018b), morphological variations among individuals (Magalhães de Oliveira et al., 2020), and between populations (Louzada \& Pessoa, 2013), the use of traits would allow to assess the effect of demography on ecological functions as has been done for other taxa (Violle et al., 2012; Siefert et al., 2015). It is important to evaluate whether intraspecific variations found in frugivorous bat diet between males and females (Alviz \& Pérez-Torres, 2020) and between reproductive stages of the females (Bohlender et al., 2018) affect processes such as seed rain and seed germination. Also, in the case of insectivorous bats, inter-individual variation on habitat exploitation and dietary preferences (Magalhães de Oliveira et al., 2020) may have differential impacts on insect control. An obstacle to conduct these studies has been the lack of complete and bat-adjusted list of traits. Therefore, we 
believe that this proposal is a benchmarking to establish a bat functional traits protocol and will help in addressing ecological and functional questions. We recommend providing separately intraspecific stats (mean, ranks, standard deviation) for each trait analyzed.

Correlation between traits: many traits presented here can be correlated with each other as we pointed out in the description of the traits. Among all the 50 traits, many of them are expected to vary allometrically, but testing the relations between them may provide a better basis for functional description of Neotropical bats instead of using only those more-common traits from the literature. Moreover, empirical evidence gathered in our revision (Table 2 and Fig. 2) indicates that the analysis of a large set of different and informative traits improves the understanding of species response to human-dominated landscapes, rather than the analysis of a single or few attributes (Martínez-Ferreira et al., 2020). Frequently, traits from wing morphology and body size are used (Pereira et al., 2019; Farneda et al., 2019; Ramírez-Mejía et al., 2020), but many others from complexes such as the tail, hindlimbs, and natural history are neglected oftentimes and can provide other type of information to an in-depth understanding of bat ecology under different environmental contexts. It should be noted that we are not suggesting using simultaneously all the 50 traits. Researchers should first decide the set of suitable traits to use according to the objectives and hypothesis of their own investigations by following the theoretical framework proposed in this paper. Collinearity between traits should be evaluated posteriorly in data analysis and then they can take their own decisions about the utility of each trait. Our objective with this proposal is to conceptualize an extensive set of traits that can be useful in ecological studies of Neotropical bats and show their applicability, but researchers should test the utility of each one of them.

Response-Effect framework: as aforementioned, in animal taxa the study of the link between traits and ecological processes is still in its infancy (Hortal et al., 2015). To better understand the nature of these relationships, empirical and experimental studies should be conducted. Given the multiple interactions in which Neotropical bats participate (e.g., frugivorous, nectarivory, insectivorous, and animalivory), their impact on ecological processes becomes more important in conditions where communities have low redundancy. Measuring simultaneously traits and ecosystem processes would contribute to disentangling the mechanisms of these interactions. It is important to document those traits that are potentially related to ecological processes (i.e., gut size, bite force, lingual papillae).

In contrast, response traits have been largely studied in environmental gradients as predictors of bat assemblages (Table 2), according to the trait-based environmental filtering (Keddy, 1992). Nevertheless, few studies have parsed out variations of response traits between land-use management types across agricultural areas. This can assess the sustainability of agricultural systems for bats, providing key information in conservation planning and decision-making (Castillo-Figueroa \& PérezTorres, 2018). Identifying also the traits that make species more vulnerable to habitat modification is fundamental to design of effective conservation strategies that reduce local extinctions of Neotropical bats (Jung \& Threlfall, 2018; Núñez et al., 2019).

Global datasets: this paper is the first step toward a functional trait-based approach in New World bats. However, conducting investigations by using the traits presented here, a plethora of ecological information can be gathered from many species in several study sites across the Neotropics. Some websites like Bat Eco-Interactions platform (Geiselman et al., 2015) have successfully facilitated datasets on bat diets and interactions, promoting scientific research on bat ecology and conservation (Castaño et al., 2018; Saldaña-Vázquez et al., 2019). Additionally, remarkable trait databases such as Atlantic Mammal Traits (Gonçalves et al., 2018), Elton Traits (Wilman et al., 2014) and PanTheria (Jones et al., 2009b) are key tools in functional investigations and are successful models of global databases from which new ones can be inspired to accomplish big and detailed bat trait databases in the Neotropics. In the same way, we want to encourage the accessibility of trait information based on this list to take advantage of big data for Neotropical studies. This trait list can also be extended to other geographical regions and bat faunas.

Outstanding functional questions: the use of bat traits can be useful in several trending topics in ecology and conservation. The most obvious but also crucial is the quantification of ecosystem processes and ecosystem services. Removal experiments have shown key findings related to biodiversity-function relationships in several groups, including the assessment of traits and their effects on ecosystem function (Díaz et al., 2003). It is wellknown the prominent role of phyllostomid bats in numerous ecological processes, nevertheless, as far as we are aware of the literature, there are very few studies that relate directly bat traits to ecosystem processes. In addition, is important to know:

- How are bat traits related to ecological processes and how this can vary across environmental gradients and human-modified landscapes?

- How do bat traits match with the traits of plants or animals they interact with?

- There is any difference between intraspecific categories (e.g., males, females) in terms of their functional contribution? And if so, is this reflected in their traits?

- How can traits explain the efficiency of bats in ecological processes different from those they are primarily involved? (e.g., carnivorous and insectivorous as seed dispersers)

- What are the trade-offs between bat traits when analyzing a specific ecological process?

On the other hand, as secondary forests are nowadays quite common in the Neotropics, understanding how this 
forest type affect animal species becomes critical (Chua \& Potts, 2018). It is important to generate indicators that effectively assess ecological resilience as well as ecological resistance, in a way that complement taxonomic studies with functional trait-based dimension using a multi-scale and multi-coverage approach (Martínez-Ferreira et al., 2020). In line with this argument, long-term studies at the Biological Dynamic of Forest Fragment Project (BDFFP) have shown the applicability of functional approach to ecological succession (Farneda et al., 2018). Thus, including the functional approach can contribute to practices of restoration ecology. The impact of agricultural systems on biodiversity and ecosystem functioning is one of the most important conservation concerns in the Neotropics (González-Maya et al., 2017). Due to this, considering the type of management is urgent to better select agriculture practices that minimize environmental impacts and improve sustainability of productive systems. Some questions rise about this regard:

- Can traits be a useful tool in rapid assessment of human impacts? Can they become bioindicators?

- Which bat traits are good predictors of sustainable ecological and conservation practices?

- To what extent a trait can vary in the same species across environmental gradients? What are the biotic and abiotic drivers?

\section{CONCLUSIONS}

In this paper, we provided an extensive guide of biological traits for studying Neotropical bats with their respective description of measurement, definitions, attributes, trait obtention and ecological information. Experimental studies are needed to test if a trait is effectively functional or not, considering that all functional traits are biological traits but not all biological traits are functional (Mlambo, 2014). This is the first contribution to achieve a bat functional traits protocol that supports the legitimate ecological reasons of each trait by using solid evidence and not just by theoretical deductions or surmises. It is essential to identify an adequate set of traits to assess bat ecological roles in ecosystems, for which is necessary to expand the base knowledge in open access databases. Also, it is important to test for correlations between traits. Finally, we encourage to use response traits in human-made landscapes, agricultural managements, and environmental gradients. Accounting this source of information, a better understanding of ecosystem functions and anthropogenic disruptions in the Neotropics can be achieved through a trait-based approach of bats.

\section{ACKNOWLEDGMENTS}

We are in debt to the reviewers and the editor for insightful comments that substantially improved the manuscript. We are also thankful to Erin Stukenholtz for the revision of the English style.

\section{AUTHORS' CONTRUBUTIONS}

D.C.-F.: conceived the idea, contributed to the theoretical and conceptual framework, wrote the paper, prepared figures and tables, reviewed drafts of the paper. J.P.-T.: wrote the paper, contributed to the theoretical and conceptual framework, reviewed drafts of the paper. The authors declare no conflict of interests.

\section{REFERENCES}

Adams, R. \& Thibault, K. 1999. Growth, development, and histology of the calcar in the little brown bat, Myotis lucifugus (Vespertilionidae). Acta chiropterrologica, 1(2): 215-221.

Adams, R.; Snode, E. \& Shaw, J. 2012. Flapping Tail Membrane in Bats Produces Potentially Important Thrust during Horizontal Takeoffs and Very Slow Flight. Plos One, 7(2): 32074. D01

Agosta, S.J. 2002. Habitat use, diet and roost selection by the big brown bat (Eptesicus fuscus) in North America: a case for conserving an abundant species. Mammal Review, 32(3): 179-198.

Aguilar-Rodríguez, P.A.; Tschapka, M.; García-Franco,J.G.;Krömer,T.\& MacSwiney, M.C. 2019. Bromeliads going batty: pollinator partitioning among sympatric chiropterophilous Bromeliaceae. AoB PLANTS, 11(2): plz014. D0I

Aguirre, L.F.; Herrel, A.; Van Damme, R. \& Matthysen, E. 2002. Ecomorphological analysis of trophic niche partitioning in a tropical savannah bat community. Proceedings of the Royal Society B, Biological Sciences, 269(1497): 1271-1278.

Aguirre, L.F.; Herrel, A.; Van Damme, R. \& Matthysen, E. 2003. The implications of food hardness for diet in bats. Functional Ecology, 17(2): 201-212.

Altringham, J.D. 2011. Bats from evolution to conservation. Oxford, Oxford University Press.

Alviz, A. \& Pérez-Torres, J. 2020. A difference between sexes: temporal variation in the diet of Carollia perspicillata (Chiroptera, Phyllostomidae) at the Macaregua cave, Santander (Colombia). Animal Biodiversity and Conservation, 43(1): 27-35.

Anderson, R.A.; McBrayer, L.D. \& Herrel, A. 2008. Bite force in vertebrates: opportunities and caveats for use of a nonpareil whole-animal performance measure. Biological Journal of the Linnean Society, 93(4): 709-720.

Arevalo, R.L.M.; Amador, L.I.; Almeida, F.C. \& Giannini, N.P. 2020. Evolution of body mass in bats: insights from a large supermatrix phylogeny. Journal of Mammalian Evolution, 27: 123-138.

Arita, H.T. 1990. Noseleaf morphology and ecological correlates in phyllostomid bats. Journal of Mammalogy, 71: 36-47.

Arita, H.T.; Vargas-Barón, J. \& Villalobos, F. 2014. Latitudinal gradients of genus richness and endemism and the diversification of New World bats. Ecography, 37(11): 1024-1033.

Ayala-Berdon, J. \& Schondube, J.E. 2011. A physiological perspective on nectar-feeding adaptation in phyllostomid bats. Physiological Biochemical Zoology, 84: 458-466.

Ayala-Berdon, J.; Galicia, R.; Flores-Ortiz, C.; Medellín, R.A. \& Schondube, J.E. 2013. Digestive capacities allow the Mexican long-nosed bat (Leptonycteris nivalis) to live in cold environments. Comparative Biochemistry and Physiology - Part A: Molecular \& Integrative Physiology, 164(4): 622-628.

Balcombe, E. \& Fenton, B. 1988. Eavesdropping by bats, the influence of echolocation call design and foraging strategies. Ethology, 79: 158-166.

Baldwin, J.W. \& Whitehead, S.R. 2015. Fruit secondary compounds mediate the retention time of seeds in the guts of Neotropical fruit bats. Oecologia, 177: 453-466 
Ballesteros-Correa, J. 2015. Efecto del manejo silvopastoril y convencional de ganadería extensiva sobre el ensamblaje de murciélagos asociados a fragmentos de bosque seco tropical en Córdoba, Colombia. (Doctoral tesis). Pontificia Universidad Javeriana, Bogotá (Colombia).

Barboza-Marquez, K.; Aguirre, L.F.; Zubieta, J.C.P. \& Kalko, E.K. 2013. Habitat use by aerial insectivorous bats of external areas of Barro Colorado Nature Monument, Panamá. Chiroptera Neotropical, 19: 44-56.

Barclay, R.M.R. 1985. Long-versus shortrange foraging strategies of hoary (Lasiurus cinereus) and silver-haired (Lasionycteris noctivagans) bats and consequences for prey selection. Canadian Journal of Zoology, 64(12): 2507-2515.

Barclay, R.M.R. 1994. Constraints on reproduction by flying vertebratesenergy and calcium. American Naturalist, 144(6): 1021-1031.

Barclay, R.M.R. \& Brigham, R.M. 1991. Prey detection, dietary niche breadth, and body size in bats: why are aerial insectivorous bats so small? American Naturalist, 137(5): 693-703.

Barclay, R.M.R. \& Harder, L.D. 2003. Life histories of bats: life in the slow lane. In: Kunz, T.H. \& Fenton, B. (Eds.). Bat Ecology. University of Chicago Press, Chicago. p. 209-253.

Bates, M.E.; Simmons, J.M. \& Zorikov, T.V. 2011. Bats use echo harmonic structure to distinguish their targets from background clutter. Science, 333: 627-630

Bernard, E. \& Fenton, M.B. 2003. Bat mobility and roosts in a fragmented landscape in central Amazonia, Brazil. Biotropica, 35(2): 262-277.

Bianconi, G.V.; Mikich, S.B.; Teixeira S.D. \& Maia, B.H.L.N.S. 2007. Attraction of fruit-eating bats with essential oils of fruits: a potential tool for forest restoration. Biotropica, 39(1): 136-140.

Blood, B. \& McFarlane, D. 1988. A new method for calculing wing area of bats. Mammalia, 52(4): 600-603.

Bohlender, E.E.; Pérez-Torres, J.; Borray-Escalante, N. \& Stevens, R.D. 2018. Dietary variation during reproduction in Seba's short-tailed fruit bat. Journal of Mammalogy, 99(2): 440-449.

Bonaccorso, F. 1979. Foraging and reproductive ecology in a Panamanian bat community. Bulletin of Florida State Museum, Biological Science, 24(4): 359-408.

Boyles, J.G. \& Storm, J.J. 2007. The perils of picky eating: dietary breadth is related to extinction risk in insectivorous bats. Plos One, 2: e672. DOI

Brokaw, A.F. \& Smotherman, M. 2020. Role of ecology in shaping external nasal morphology in bats and implications for olfactory tracking. Plos One, 15(1): e0226689. DOI

Cadotte, M.W.; Carscadden, K. \& Mirotchnick, N. 2011. Beyond species: functional diversity and the maintenance of ecological processes and services. Journal of Applied Ecology, 48(5): 1079-1087.

Camargo, N. \& Oliveira, H. 2012. Sexual Dimorphism in Sturnira lilium (Chiroptera, Phyllostomidae): Can Pregnancy and Pup Carrying Be Responsible for Differences in Wing Shape? Plos One, 7(11): e49734. D0I

Castaño, J.H.; Carranza, J.A. \& Pérez-Torres, J. 2018. Diet and trophic structure in assemblages of montane frugivorous phyllostomid bats. Acta Oecologica, 91: 81-90.

Castillo-Figueroa, D. 2018a. Beyond specimens: linking biological collections, functional ecology and biodiversity conservation. Revista Peruana de Biología, 25(3): 343-348.

Castillo-Figueroa, D. 2018b. Fluctuating asymmetry of three bat species in extensive livestock systems of Córdoba Department, Colombia. Revista Colombiana de Ciencia Animal, 10(2): 143-153.

Castillo-Figueroa, D. 2020a. Ecological morphology of neotropical bat wing structures. Zoological Studies, 59: 1-14. Available: http://zoolstud.sinica. edu.tw/Journals/59/59-60.html.

Castillo-Figueroa, D. 2020b. Why bats matters: a critical assessment of batmediated ecological processes in the Neotropics. European Journal of Ecology, 6(1): 77-101.
Castillo-Figueroa, D. \& Pérez-Torres, J. 2018. Respuestas funcionales de murciélagos asociados a fragmentos de bosque seco tropical en Córdoba (Colombia): implicaciones del tipo de manejo en sistemas de ganadería extensiva. Revista Biodiversidad Neotropical, 8(3): 197-211.

Castillo-Figueroa, D.; Stukenholtz, E.; Stevens, R.D. \& Pérez-Torres, J. 2018. Cases of induced alloparental care in Seba's short-tailed fruit bat. Neotropical Biology and Conservation, 13(4): 347-349.

Chacón-Pacheco, J.J. \& Ballesteros-Correa, J. 2019. Mejor condición corporal de Artibeus lituratus en sistemas silvopastoriles que en sistemas convencionales de ganadería en Córdoba, Colombia. Oecologia Australis, 23(3): 589-605.

Chave, J.; Coomes, D.; Jansen, S.; Lewis, S.L.; Swenson, N.G. \& Zanne, A.E. 2009. Towards a worldwide wood economics spectrum. Ecology Letters, 12(4): 351-366.

Chiu, C. \& Moss, C.F. 2007. The role of the external ear in vertical sound localization in the free flying bat, Eptesicus fuscus. The Journal of the Acoustical Society of America, 121(4): 2227-2235.

Chua, S.C. \& Potts, M.D. 2018. The role of plant functional traits in understanding forest recovery in wet tropical secondary forests. The Science of the Total Environment, 642: 1252-1262.

Cipollini, M. \& Levey, D.J. 1997. Secondary metabolites of fleshy vertebratedispersed fruits: adaptive hypotheses and implications for seed dispersal. American Naturalist, 150(3): 346-372.

Cisneros, L.M.; Burgio, K.R.; Dreiss, L.M.; Klingbeil, B.T.; Patterson, B.D.; Presley, S.J. \& Willig, M.R. 2014. Multiple dimensions of bat biodiversity along an extensive tropical elevational gradient. Journal of Animal Ecology, 83(5): 1124-1136.

Cisneros, L.M.; Fagan, M.E. \& Willig, M.R. 2015. Effects of human-modified landscapes on taxonomic, functional and phylogenetic dimensions of bat biodiversity. Diversity and Distributions, 21(5): 523-533.

Cisneros, L.M.; Fagan, M.E. \& Willig, M.R. 2016. Environmental and spatial drivers of taxonomic, functional, and phylogenetic characteristics of bat communities in human-modified landscapes. PeerJ, 4: e2551. D0I

Claramunt, S.; Derryberry, E.P.; Remsen, J.V. \& Brumfield, R.T. 2012. High dispersal ability inhibits speciation in a continental radiation of passerine birds. Proceedings of the Royal Society of London Series B, 279(1733): 1567-1574.

Cooper, I. \& Sears, K. 2013. How to grow a bat wing. In: Adams, R.A. \& Pedersenm, S.C. (Eds.). Bat evolution, ecology, and conservation. New York, Springer-Verlag. p. 3-20.

Córdova-Tapia, F. \& Zambrano, L. 2016. Fish functional groups in a tropical wetland of the Yucatán Península, México. Neotropical Ichthyology, 14(2): e150162. D0I

Cornelissen, J.H.C.; Lavorel, S.; Garnier, E.; Díaz, S.; Buchmann, N.; Gurvich, D.E.; Reich, P.B.; ter Steege, H.; Morgan, H.D.; van der Heijden, M.G.A.; Pausas, J.G. \& Poorter, H. 2003. A handbook of protocols for standardized and easy measurement of plant functional traits worldwide. Australian Journal of Botany, 51(4): 335-380.

Cortés-Gómez, A.M.; Ramírez-Pinilla, M.P. \& Urbina-Cardona, N. 2015. Protocolo para la medición de rasgos funcionales en anfibios, In: SalgadoNegret, B. (Ed.). La Ecología funcional como aproximación al estudio, manejo y conservación de la biodiversidad: protocolos y aplicaciones. Bogotá, Instituto de Investigación de Recursos Biológicos Alexander Von Humboldt (IAvH). p. 126-180.

Crichton, E.G. \& Krutzsch, P.H. 2000. Reproductive biology of bats. Cambridge, Academic Press.

Cruzblanca-Castro, M.; Martínez-Gómez, M. \& Ayala-Berdon, J. 2018. Food processing does not affect energy intake in the nectar-feeding bat Anoura geoffroyi. Mammalian Biology, 88: 176-179.

Davies, N.B.; Krebs, K.R. \& West, S.A. 2012. An introduction to behavioural ecology. Wiley-Blackwell, West Sussex. 
Davis, J.L.; Santana, S.E.; Dumont, E.R. \& Grosse, I. 2010. Predicting bite force in mammals: two-dimensional versus three-dimensional lever models. Journal of Experimental Biology, 213(11): 1844-1851.

Denzinger, A. \& Schnitzler, H.U. 2013. Bat guilds, a concept to classify the highly diverse foraging and echolocation behaviors of microchiropteran bats. Frontiers in Physiology, 4: 1-15.

Denzinger, A.; Kalko, E.K.V.; Tschapka, M.; Grinnell, A.D. \& Schnitzler, H.U. 2016. Guild structure and niche differentiation in echolocating bats. In: Fenton, M.B.; Grinnell, A.D.; Popper, A.N. \& Fay, R.R. (Eds.). Bat bioacoustics. New York, Springer. p. 141-166.

Di Blanco, Y.E.; Spørring, K.S. \& Di Bitetti, M.S. 2017. Daily activity pattern of reintroduced giant anteaters (Myrmecophaga tridactyla): effects of seasonality and experience. Mammalia, 81(1): 11-21.

Díaz, S.; Symstad, A.J.; Stuart Chapin, F.; Wardle, D.A. \& Huenneke, L.F. 2003. Functional diversity revealed by removal experiments. Trends in Ecology and Evolution, 18(3): 140-146.

Dietz, C. 1973. Bat Walking behavior. Journal of Mammalogy, 54(3): 790-792.

Dietz, C.; Dietz, I. \& Siemers, B.M. 2006. Wing measurement variations in the five European horseshoe bat species (Chiroptera: Rhinolophidae). Journal of Mammalogy, 87(6): 1241-1251.

Duchamp, J.E. \& Swihart, R.K. 2008. Shifts in bat community structure related to evolved traits and features of human-altered landscapes. Landscape Ecology, 23(7): 849-860.

Duchamp, J.E.; Sparks, D.W. \& Swihart, R.K. 2010. Exploring the "nutrient hot spot" hypothesis at trees used by bats. Journal of Mammalogy, 91(1): 48-53.

Dumont, E.R. \& Herrel, A. 2003. The effects of gape angle and bite point on bite force in bats. Journal of Experimental Biology, 206(3): 2117-2123.

Esbérard, C.E.L.; de Lima, I.P.; Nobre, P.H.; Althoff, S.L.; Jordão-Nogueira, T.; Dias, D.; Carvalho, F.; Fabián, M.E.; Sekiama, M.L. \& Sobrinho, A.S. 2011. Evidence of vertical migration in the Ipanema bat Pygoderma bilabiatum (Chiroptera: Phyllostomidae: Stenodermatinae). Zoologia, 28(6): 717-724.

Estrada-Villegas, S.; Meyer, C. \& Kalko, E. 2010. Effects of tropical forest fragmentation on aerial insectivorous bats in a land-bridge island system. Biological Conservation, 143(3): 597-608.

Farneda, F.Z.; Meyer, C.F.J. \& Grelle, C.E.V. 2019. Effects of land-use change on functional and taxonomic diversity of Neotropical bats. Biotropica, 52(1): 120-128.

Farneda, F.Z.; Rocha, R.; López-Baucells, A.; Groenenberg, M.; Silva, I.; Palmeirim, J.M.; Bobrowiec, P. \& Meyer, C.F.J. 2015. Trait-related responses to habitat fragmentation in Amazonian bats. Journal of applied Ecology, 52(5): 1381-1391.

Farneda, F.Z.; Rocha, R.; López-Baucells, A.; Sampaio, E.M.; Palmeirim, J.M.; Bobrowiec, P.E.D.; Grelle, C.E.V. \& Meyer, C.F.J. 2018. Functional recovery of Amazonian bat assemblages following secondary forest succession. Biological Conservation, 218: 192-199.

Fenton, M.B. 1980. Adaptiveness and ecology of echolocation in terrestrial (aerial) systems. In: Busnel, R.G. \& Fish, J.F. (Eds.). Animal Sonar Systems. New York, Plenum Press. p. 427-446.

Fenton, M.B.; Acharya, L.; Audet, D.; Hickey, M.B.C.; Merriman, C.; Obrist, M.K.; Syme, D.M. \& Adkins, B. 1992. Phyllostomid bats (Chiroptera: Phyllostomidae) as indicators of habitat disruption in the Neotropics. Biotropica, 24(3): 440-446.

Ferro-Muñoz, N.; Giraldo, A. \& Murillo-García, 0.E. 2018. Composition, trophic structure and activity patterns of the understory bats of the Bitaco forest reserve. Acta Biológica Colombiana, 23(2): 170-178.

Findley, J.S. \& Wilson, D.E. 1982. Ecological significance of chiropteran morphology. In: Kunz, T.H. (Ed.). Ecology of bats. New York, Plenum Press. p. 243-260.
Findley, J.S.; Studier, E.H. \& Wilson, D.E. 1972. Morphological properties of bat wings. Journal of Mammalogy, 53(3): 429-444.

Fish, F.; Blood, B. \& Clark, B. 1991. Hydrodynamics of the Feet of Fish-Catching Bats: Influence of the Water Surface on Drag and Morphological Design. Journal of Experimental Zoology, 25(8): 164-173.

Fleming, T.H. 1986. Opportunism versus specialization: the evolution of feeding strategies in frugivorous bats. In: Estrada, A. \& Fleming, T.H. (Eds.). Frugivores and Seed Dispersal. Dordrecht, Dr. W. Junk Publishers. p. $105-118$.

Fleming, T.H. 1988. The short-tailed fruit Bat: a study in plant-animal interactions. Chicago, University of Chicago Press.

Fleming, T.H. 1991. The relationship between body size, diet, and habitat use in frugivorous bats, genus Carollia (Phyllostomidae). Journal of Mammalogy, 72(3): 493-501.

Fleming, T.H.; Geiselman, C.\& Kress, W.J. 2009. The evolution of bat pollination: a phylogenetic perspective. Annals of Botany, 104: 1017-1043.

Fleming, T.H.; Hooper, E.T. \& Wilson, D.E. 1972. Three central American bat communities structure, reproductive cycles and movement patterns. Ecology, 53: 555-569.

Frank, H.K.; Frishkoff, L.O.; Mendenhall, C.D.; Daily, G.C. \& Hadly, E.A. 2017. Phylogeny, traits, and biodiversity of a Neotropical bat assemblage: Close relatives show similar responses to local deforestation. American Naturalist, 190(2): 200-212.

Frick, W.F.; Kingston, T. \& Flanders, J. 2019. A review of the major threats and challenges to global bat conservation. Annals of the New York Academy of Sciences, 1469(Special Issue): 5-25.

Galindo-González, J. 1998. Dispersión de semillas por murciélagos: su importancia en la conservación y regeneración del bosque tropical. Acta Zoológica Mexicana, 73: 57-74.

Garbino, G.S. \& Tavares, V.D.C. 2018. Roosting ecology of Stenodermatinae bats (Phyllostomidae): Evolution of foliage roosting and correlated phenotypes. Mammal Review, 48: 75-89.

García-García, J.L.; Santos-Moreno, A. \& Kraker-Castañeda, C. 2014. Ecological traits of Phyllostomid bats associated with sensitivity to tropical forest fragmentation in Los Chimalapas, México. Tropical Conservation Science, 7(3): 457-474.

García-Morales, R.; Moreno, C.E.; Badano, E.I.; Zuria, I.; Galindo-Gonzalez, J.; Rojas-Martínez, A.E. \& Ávila-Gómez, E.S. 2016. Deforestation Impacts on Bat Functional Diversity in Tropical Landscapes. Plos One, 11(12): e0166765. DOI

Gardiner, J.D.; Codd, J.R. \& Nudds, R.L. 2011a. An association between ear and tail morphologies of bats and their foraging style. Canadian Journal of Zoology, 89: 90-99.

Gardiner, J.D.; Dimitriadis, G.; Codd, J.R. \& Nudds, R.L. 2011b. A potential role for bat tail membranes in flight control. Plos One, 6: e18214. DOI

Geiselman, C.K.; Defex, T.; Brown, T. \& Younger, S. 2015. Database bat Eco - interactions. Available: http://www.batplant.org/search. Access: 01/03/2020

Giannini, N.P. \& Brenes, F.V. 2001. Flight cage observations of foraging mode in Phyllostomus discolor, P. hastatus, and Glossophaga commissarisi. Biotropica, 33(3): 546-550.

Giannini, N.P. \& Kalko, E.K. 2004. Trophic structure in a large assemblage of Phyllostomid bats in Panama. Oikos, 105(2): 209-222.

Giannini, N.P.; Gunnell, G.; Habersetzer, J. \& Simmons, N. 2012. Early evolution of body size in bats. In: Gunnell, G. \& Simmons, N. (Eds.). Evolutionary history of bats: fossils, molecules and morphology. Cambridge, Cambridge University Press. p. 530-555.

Gómez-Ortiz, Y. \& Moreno, C.E. 2017. La diversidad funcional en comunidades animales: una revisión que hace énfasis en los vertebrados. Animal Biodiversity and Conservation, 40(2): 165-174. 
Gonçalves, F.; Bovendorp, R.S.; Beca, G.; Bello, C.; Costa-Pereira, R.; Muylaert, R.L.; Rodarte, R.R.; Villar, N.; Souza, R.; Graipel, M.E.; Cherem, J.J.; Faria, D.; Baumgarten, J.; Alvarez, M.R.; Vieira, E.M.; Cáceres, N.; Pardini, R.; Leite, Y.L.R.; Costa, L.P.; Mello, M.A.R.; Fischer, E.; Passos, F.C.; Varzinczak, L.H.; Prevedello, J.A.; Cruz-Neto, A.P.; Carvalho, F.; Percequillo, A.R.; Paviolo, A.; Nava, A.; Duarte, J.M.B.; de la Sancha, N.U.; Bernard, E.; Morato, R.G.; Ribeiro, J.R.; Becker, R.G.; Paise, G.; Tomasi, P.S.; VélezGarcia, F.; Melo, G.L.; Sponchiado, J.; Cerezer, F.; Barros, M.A.S.; de Souza, A.Q.S.; dos Santos, C.C.; Giné, G.A.F.; Kerches-Rogeri, P.; Weber, M.M.; Ambar, G.; Cabrera-Martinez, L.V.; Eriksson, A.; Silveira, M.; Santos, C.F.; Alves, L.; Barbier, E.; Rezende, G.C.; Garbino, G.S.T.; Rios, É.0.; Silva, A.; Nascimento, A.T.A.; de Carvalho, R.S.; Feijó, A.; Arrabal, J.; Agostini, I.; Lamattina, D.; Costa, S.; Vanderhoeven, E.; de Melo, F.R.; de Oliveira Laroque, P.; Jerusalinsky, L.; Valença-Montenegro, M.M.; Martins, A.B.; Ludwig, G.; de Azevedo, R.B.; Anzóategui, A.; da Silva, M.X.; Moraes, M.F.D.; Vogliotti, A.; Gatti, A.; Püttker, T.; Barros, C.S.; Martins, T.K.; Keuroghlian, A.; Eaton, D.P.; Neves, C.L.; Nardi, M.S.; Braga, C.; Gonçalves, P.R.; Srbek-Araújo, A.C.; Mendes, P.; de Oliveira, J.A.; Soares, F.A.M.; Rocha, P.A.; Crawshaw-Jr., P.; Ribeiro, M.C. \& Galetti, M. 2018. Atlantic Mammal Traits: a data set of morphological traits of mammals in the Atlantic Forest of South America. Ecology, 99(2): 498. D01

González-Maya, J.F.; Martínez-Meyer, E.; Medellín, R. \& Ceballos, G. 2017. Distribution of mammal functional diversity in the Neotropical realm: Influence of land-use and extinction risk. Plos One, 12(4): e0175931. D0l

Granatosky, M.C. 2018. Forelimb and hindlimb loading patterns during quadrupedal locomotion in the large flying fox (Pteropus vampyrus) and common vampire bat (Desmodus rotundus). Journal of Zoology, 305: 63-72.

Gregorin, R. 2003. Comparative morphology of the tongue in free-tailed bats (Chiroptera, Molossidae). Iheringia, Série Zoologia, 93(2): 213-221.

Gregorin, R.; Bernard E.; Lobão, K.W.; Oliveira, L.F.; Machado, F.S.; Gil, B.B. \& Tavares, V. 2017. Vertical stratification in bat assemblages of the Atlantic Forest of south-eastern Brazil. Journal of Tropical Ecology, 3(5): 299-308.

Gross, N.; Le Bagousse-Pinguet, Y.; Liancourt, P.; Berdugo, M.; Gotelli, N.J. \& Maestre, F.T. 2017. Functional trait diversity maximizes ecosystem multifunctionality. Nature Ecology \& Evolution, 1(5): 132. DOI

Gunawan, G.; Saragih, G.R.; Umardani, Y.; Karnati, S.; Wihadmadyatami, H. \& Kusindarta, D.L. 2019. Morphological study of the lingual papillae in the fruit bat (Rousettus amplexicaudatus) by scanning electron microscopy and light microscopy. Anatomia, Histologia, Embryologia, 49(2): 173-183.

Håkansson, J.; Jakobsen, L.; Hedenström, A. \& Johansson, L.C. 2017. Body lift, drag and power are relatively higher in large-eared than in smalleared bat species. Journal of the Royal Society Interface, 14: 20170455. D0I

Heithaus, R. \& Fleming, T. 1978. Foraging Movements of a Frugivorous Bat, Carollia perspicillata (Phyllostomatidae). Ecological Monographs, 48(2): 127-143.

Herrel, A.; De Smet, A.; Aguirre, L.F. \& Aerts, P. 2008. Morphological and mechanical determinants of bite force in bats: do muscles matter? Journal of Experimental Biology, 211: 86-91.

Hodgson, J.G.;Wilson, P.J.; Hunt, R.; Grime, J.P. \& Thompson K. 1999. Allocating C-S-R plant functional types: a soft approach to a hard problem. Oikos, 85: 282-294.

Holderied, M.; Korine, C. \& Moritz, T. 2010. Hemprich's longeared bat (Otonycteris hemprichii) as a predator of scorpions: whispering echolocation, passive gleaning and prey selection. Journal of Comparative Physiology A, 197: 425-433.

Hortal, J.; de Bello, F.; Diniz, J.A.F.; Lewinsohn, T.M.; Lobo, J.M. \& Ladle, R.J. 2015. Seven shortfalls that beset large-scale knowledge of biodiversity. Annual Review of Ecology, Evolution, and Systematics, 46: 523-549.
Houston, R.D.; Boonman, A.M. \& Jones, G. 2004. Do echolocation signal parameters restrict bats' choice of prey? In: Thomas, J.A.; Moss, C.F. \& Vater, M. (Eds.). Echolocation in Bats and Dolphins. Chicago, Chicago University Press. p. 339-345.

Huihua, Z.; Shuyi, Z.; Mingxue, Z. \& Jiang, Z. 2003 Correlations between call frequency and ear length in bats belonging to the families Rhinolophidae and Hipposideridae. Journal of Zoology, 259: 189-195.

Hurtado, N.; Sepúlveda, R. \& Pacheco, V. 2015. Sexual Size Dimorphism of a Sensory Structure in a Monomorphic Bat. Acta Chiropterologica, 17(1): 75-83.

Hutson, A.M.; Mickleburgh, S.P. \& Racey P.A. 2001. Microchiropteran Bats: global status survey and conservation action plan. Switzerland, IUCN/SSC.

Jacomassa, F.A.F. \& Pizo, M.A. 2010. Birds and bats diverge in the qualitative and quantitative components of seed dispersal of a pioneer tree. Acto Oecologica, 36(5): 493-496.

Janzen, D.H. 1970. Herbivores and the number of tree species in tropical forests. American Naturalist, 104(940): 501-528.

Jones, G. 1999. Scaling of echolocation call parameters in bats. Journal of Experimental Biology, 202(23): 3359-3367.

Jones, G. \& Holderied, M.W. 2007. Bat echolocation calls: adaptation and convergent evolution. Proceedings of the Royal Society of London $B$, 274(1612): 905-912

Jones, G.; Jacobs, D.S.; Kunz, T.H.; Willig, M.R. \& Racey, P.A. 2009a. Carpe noctem: the importance of bats as bioindicators. Endangered Species Research, 8: 93-115.

Jones, K.E.; Bielby, J.; Cardillo, M.; Fritz, S.A.; O'Dell, J.; Orme, C.D.L.; Safi, K.; Sechrest, W.; Boakes, E.H.; Carbone, C.; Connolly, C.; Cutts, M.J.; Foster, J.K.; Grenyer, R.; Habib, M.; Plaster, C.A.; Price, S.A.; Rigby, E.A.; Teacher, J.R.A.; Bininda-Emonds, O.R.P.; Gittleman, J.L.; Mace, G.M.M. \& Purvis, A. 2009b. PanTHERIA: a species-level database of life history, ecology, and geography of extant and recently extinct mammals. Ecology, 90(9): 2648.

Jung, K. \& Threlfall, C.G. 2018. Trait-dependent tolerance of bats to urbanization: A global meta-analysis. Proceedings of the Royal Society $B$, Biological Sciences, 285(1885): 1-9. D0I

Kalcounis, M.C. \& Brigham, R.M. 1995. Intraspecific variation in wing loading affects habitat use by little brown bats (Myotis lucifugus). Canadian Journal of Zoology, 73(1): 89-95.

Kalka, M. \& Kalko, E.K.V. 2006. Gleaning bats as underestimated predators of herbivorous insects: diet of Micronycteris microtis (Phyllostomidae) in Panama. Journal of Tropical Ecology, 22: 1-10.

Kalko, E.K.V. 1995. Insect pursuit, prey capture and echolocation in pipistrelle bats (Microchiroptera). Animal Behaviour, 50: 861-880.

Kalko, E.K.V.; Estrada Villegas, S.; Schmidt, M.; Wegmann, M. \& Meyer, C.F. 2008. Flying high-assessing the use of the aerosphere by bats. Integrative and Comparative Biology, 48: 60-73.

Kalko, E.K.V.; Friemel, D.; Handley-Jr., C.0. \& Schnitzler, H.-U. 1999. Roosting and foraging of two neotropical bats, Tonatia silvicola and Trachops cirrhosis (Phyllostomidae). Biotropica, 31(2): 344-353.

Kalko, E.K.V.; Herre, E.A. \& Handley, C.0. 1996. Relation of fig fruit characteristics to fruit-eating bats in New and Old World tropics. Journal of Biogeography, 23(4): 565-576.

Karasov, W.; Martınez del Rio, C. \& Caviedes-Vidal, E. 2011. Ecological physiology of diet and digestive systems. Annual Review of Physiology, 73: 69-93.

Kasso, M. \& Balakrishnan, M. 2013. Ecological and Economic Importance of Bats (Order Chiroptera). ISRN Biodiversity, 2013(187415): 1-9 DOI

Kattge, J.; Bönisch, G.; Díaz, S.; Lavorel, S.; Prentice, I.C.; Leadley, P.; Tautenhahn, S.; Werner, G.D.A.; Aakala, T.; Abedi, M.; Acosta, A.T.R.; Adamidis, G.G.; Adamson, K.; Aiba, M.; Albert, C.H.; Alcántara, J.M.; Alcázar C., C.; Aleixo, I.; Ali, H.; Amiaud, B.; Ammer, C.; Amoroso, M.M.; 
Anand, M.; Anderson, C.; Anten, N.; Antos, J.; Apgaua, D.M.G.; Ashman, T.-L.; Asmara, D.H.; Asner, G.P.; Aspinwall, M.; Atkin, 0.; Aubin, I.; Baastrup-Spohr, L.; Bahalkeh, K.; Bahn, M.; Baker, T.; Baker, W.J.; Bakker, J.P.; Baldocchi, D.; Baltzer, J.; Banerjee, A.; Baranger, A.; Barlow, J.; Barneche, D.R.; Baruch, Z.; Bastianelli, D.; Battles, J.; Bauerle, W.; Bauters, M.; Bazzato, E.; Beckmann, M.; Beeckman, H.; Beierkuhnlein, C.; Bekker, R.; Belfry, G.; Belluau, M.; Beloiu, M.; Benavides, R.; Benomar, L.; Berdugo-Lattke, M.L.; Berenguer, E.; Bergamin, R.; Bergmann, J.; Carlucci, M.B.; Berner, L.; Bernhardt-Römermann, M.; Bigler, C.; Bjorkman, A.D.; Blackman, C.; Blanco, C.; Blonder, B.; Blumenthal, D.; Bocanegra-González, K.T.; Boeckx, P.; Bohlman, S.; Böhning-Gaese, K.; Boisvert-Marsh, L.; Bond, W.; Bond-Lamberty, B.; Boom, A.; Boonman, C.C.F.; Bordin, K.; Boughton, E.H.; Boukili, V.; Bowman, D.M.J.S.; Bravo, S.; Brendel, M.R.; Broadley, M.R.; Brown, K.A.; Bruelheide, H.; Brumnich, F.; Bruun, H.H.; Bruy, D.; Buchanan, S.W.; Bucher, S.F.; Buchmann, N.; Buitenwerf, R.; Bunker, D.E.; Bürger, J.; Burrascano, S.; Burslem, D.F.R.P.; Butterfield, B.J.; Byun, C.; Marques, M.; Scalon, M.C.; Caccianiga, M.; Cadotte, M.; Cailleret, M.; Camac, J.; Camarero, J.J.; Campany, C.; Campetella, G.; Campos, J.A.; Cano-Arboleda, L.; Canullo, R.; Carbognani, M.; Carvalho, F.; Casanoves, F.; Castagneyrol, B.; Catford, J.A.; CavenderBares, J.; Cerabolini, B.E.L.; Cervellini, M.; Chacón-Madrigal, E.; Chapin, K.; Chapin, F.S.; Chelli, S.; Chen, S.-C.; Chen, A.; Cherubini, P.; Chianucci, F.; Choat, B.; Chung, K.-S.; Chytrý, M.; Ciccarelli, D.; Coll, L.; Collins, C.G.; Conti, L.; Coomes, D.; Cornelissen, J.H.C.; Cornwell, W.K.; Corona, P.; Coyea, M.; Craine, J.; Craven, D.; Cromsigt, J.P.G.M.; Csecserits, A.; Cufar, K.; Cuntz, M.; Silva, A.C. da; Dahlin, K.M.; Dainese, M.; Dalke, I.; Fratte, M.D.; Dang-Le, A.T.; Danihelka, J.; Dannoura, M.; Dawson, S.; Beer, A.J. de; De Frutos, A.; De Long, J.R.; Dechant, B.; Delagrange, S.; Delpierre, N.; Derroire, G.; Dias, A.S.; Diaz-Toribio, M.H.; Dimitrakopoulos, P.G.; Dobrowolski, M.; Doktor, D.; Dřevojan, P.; Dong, N.; Dransfield, J.; Dressler, S.; Duarte, L.; Ducouret, E.; Dullinger, S.; Durka, W.; Duursma, R.; Dymova, 0.; E-Vojtkó, A.; Eckstein, R.L.; Ejtehadi, H.; Elser, J.; Emilio, T.; Engemann, K.; Erfanian, M.B.; Erfmeier, A.; Esquivel-Muelbert, A.; Esser, G.; Estiarte, M.; Domingues, T.F.; Fagan, W.F.; Fagúndez, J.; Falster, D.S.; Fan, Y.; Fang, J.; Farris, E.; Fazlioglu, F.; Feng, Y.; Fernandez-Mendez, F.; Ferrara, C.; Ferreira, J.; Fidelis, A.; Finegan, B.; Firn, J.; Flowers, T.J.; Flynn, D.F.B.; Fontana, V.; Forey, E.; Forgiarini, C.; François, L.; Frangipani, M.; Frank, D.; Frenette-Dussault, C.; Freschet, G.T.; Fry, E.L.; Fyllas, N.M.; Mazzochini, G.G.; Gachet, S.; Gallagher, R.; Ganade, G.; Ganga, F.; García-Palacios, P.; Gargaglione, V.; Garnier, E.; Garrido, J.L.; Gasper, A.L. de; Gea-Izquierdo, G.; Gibson, D.; Gillison, A.N.; Giroldo, A.; Glasenhardt, M.-C.; Gleason, S.; Gliesch, M.; Goldberg, E.; Göldel, B.; Gonzalez-Akre, E.; Gonzalez-Andujar, J.L.; González-Melo, A.; González-Robles, A.; Graae, B.J.; Granda, E.; Graves, S.; Green, W.A.; Gregor, T.; Gross, N.; Guerin, G.R.; Günther, A.; Gutiérrez, A.G.; Haddock, L.; Haines, A.; Hall, J.; Hambuckers, A.; Han, W.; Harrison, S.P.; Hattingh, W.; Hawes, J.E.; He, T.; He, P.; Heberling, J.M.; Helm, A.; Hempel, S.; Hentschel, J.; Hérault, B.; Hereş, A.M.; Herz, K.; Heuertz, M.; Hickler, T.; Hietz, P.; Higuchi, P.; Hipp, A.L.; Hirons, A.; Hock, M.; Hogan, J.A.; Holl, K.; Honnay, O.; Hornstein, D.; Hou, E.; Hough-Snee, N.; Hovstad, K.A.; Ichie, T.; Igić, B.; Illa, E.; Isaac, M.; Ishihara, M.; Ivanov, L.; Ivanova, L.; Iversen, C.M.; Izquierdo, J.; Jackson, R.B.; Jackson, B.; Jactel, H.; Jagodzinski, A.M.; Jandt, U.; Jansen, S.; Jenkins, T.; Jentsch, A.; Jespersen, J.R.P.; Guo-Feng, J.; Johansen, J.L.; Johnson, D.; Jokela, E.J.; Joly, C.A.; Jordan, G.J.; Joseph, G.S.; Junaedi, D.; Junker, R.R.; Justes, E.; Kabzems, R.; Kane, J.; Zdenek, K.; Kattenborn, T.; Kavelenova, L.; Kearsley, E.; Kempel, A.; Kenzo, T.; Kerkhoff, A.; Khalil, M.I.; Kinlock, N.L.; Kissling, W.D.; Kitajima, K.; Kitzberger, T.; Kjøller, R.; Klein, T.; Kleyer, M.; Klimešová, J.; Klipel, J.; Kloeppel, B.; Klotz, S.; Knops, J.M.H.; Kohyama, T.; Koike, F.; Kollmann, J.; Komac, B.; Komatsu, K.; König, C.; Kraft, N.J.B.; Kramer, K.; Kreft, H.; Kühn, I.; Kumarathunge, D.; Kuppler, J.; Kurokawa, H.; Kurosawa,
Y.; Kuyah, S.; Laclau, J.-P.; Lafleur, B.; Lallai, E.; Lamb, E.; Lamprecht, A.; Larkin, D.J.; Laughlin, D.; Bagousse-Pinguet, Y.L.; le Maire, G.; le Roux, P.C.; le Roux, E.; Lee, T.; Lens, F.; Lewis, S.L.; Lhotsky, B.; Yuanzhi, L.; Xine, L.; Lichstein, J.W.; Liebergesell, M.; Lim, J.Y.; Lin, Y.-S.; Linares, J.C.; Liu, C.; Liu, D.; Liu, U.; Livingstone, S.; Llusià, J.; Lohbeck, M.; López-García, Á.; Lopez-Gonzalez, G.; Lososová, Z.; Louault, F.; Lukács, B.A.; Lukeš, P.; Luo, Y.; Lussu, M.; Ma, S.; Pereira, C.M.R.; Mack, M.; Maire, V.; Mäkelä, A.; Mäkinen, H.; Malhado, A.C.M.; Mallik, A.; Manning, P.; Manzoni, S.; Marchetti, Z.; Marchino, L.; Marcilio-Silva, V.; Marcon, E.; Marignani, M.; Markesteijn, L.; Martin, A.; Martínez-Garza, C.; Martínez-Vilalta, J.; Mašková, T.; Mason, K.; Mason, N.; Massad, T.J.; Masse, J.; Mayrose, I.; McCarthy, J.; McCormack, M.L.; McCulloh, K.; McFadden, I.R.; McGill, B.J.; McPartland, M.Y.; Medeiros, J.S.; Medlyn, B.; Meerts, P.; Mehrabi, Z.; Meir, P.; Melo, F.P.L.; Mencuccini, M.; Meredieu, C.; Messier, J.; Mészáros, I.; Metsaranta, J.; Michaletz, S.T.; Michelaki, C.; Migalina, S.; Milla, R.; Miller, J.E.D.; Minden, V.; Ming, R.; Mokany, K.; Moles, A.T.; Molnár V, A.; Molofsky, J.; Molz, M.; Montgomery, R.A.; Monty, A.; Moravcová, L.; Moreno-Martínez, A.; Moretti, M.; Mori, A.S.; Mori, S.; Morris, D.; Morrison, J.; Mucina, L.; Mueller, S.; Muir, C.D.; Müller, S.C.; Munoz, F.; Myers-Smith, I.H.; Myster, R.W.; Nagano, M.; Naidu, S.; Narayanan, A.; Natesan, B.; Negoita, L.; Nelson, A.S.; Neuschulz, E.L.; Ni, J.; Niedrist, G.; Nieto, J.; Niinemets, Ü.; Nolan, R.; Nottebrock, H.; Nouvellon, Y.; Novakovskiy, A.; Nystuen, K.0.; O'Grady, A.; O'Hara, K.; O'Reilly-Nugent, A.; Oakley, S.; Oberhuber, W.; Ohtsuka, T.; Oliveira, R.; Öllerer, K.; Olson, M.E.; Onipchenko, V.; Onoda, Y.; Onstein, R.E.; Ordonez, J.C.; Osada, N.; Ostonen, I.; Ottaviani, G.; Otto, S.; Overbeck, G.E.; Ozinga, W.A.; Pahl, A.T.; Paine, C.E.T.; Pakeman, R.J.; Papageorgiou, A.C.; Parfionova, E.; Pärtel, M.; Patacca, M.; Paula, S.; Paule, J.; Pauli, H.; Pausas, J.G.; Peco, B.; Penuelas, J.; Perea, A.; Peri, P.L.; Petisco-Souza, A.C.; Petraglia, A.; Petritan, A.M.; Phillips, 0.L.; Pierce, S.; Pillar, V.D.; Pisek, J.; Pomogaybin, A.; Poorter, H.; Portsmuth, A.; Poschlod, P.; Potvin, C.; Pounds, D.; Powell, A.S.; Power, S.A.; Prinzing, A.; Puglielli, G.; Pyšek, P.; Raevel, V.; Rammig, A.; Ransijn, J.; Ray, C.A.; Reich, P.B.; Reichstein, M.; Reid, D.E.B.; RéjouMéchain, M.; Dios, V.R. de; Ribeiro, S.; Richardson, S.; Riibak, K.; Rillig, M.C.; Riviera, F.; Robert, E.M.R.; Roberts, S.; Robroek, B.; Roddy, A.; Rodrigues, A.V.; Rogers, A.; Rollinson, E.; Rolo, V.; Römermann, C.; Ronzhina, D.; Roscher, C.; Rosell, J.A.; Rosenfield, M.F.; Rossi, C.; Roy, D.B.; Royer-Tardif, S.; Rüger, N.; Ruiz-Peinado, R.; Rumpf, S.B.; Rusch, G.M.; Ryo, M.; Sack, L.; Saldaña, A.; Salgado-Negret, B.; Salguero-Gomez, R.; Santa-Regina, I.; Santacruz-García, A.C.; Santos, J.; Sardans, J.; Schamp, B.; Scherer-Lorenzen, M.; Schleuning, M.; Schmid, B.; Schmidt, M.; Schmitt, S.; Schneider, J.V.; Schowanek, S.D.; Schrader, J.; Schrodt, F.; Schuldt, B.; Schurr, F.; Garvizu, G.S.; Riviera Semchenko, M.; Seymour, C.; Sfair, J.C.; Sharpe, J.M.; Sheppard, C.S.; Sheremetiev, S.; Shiodera, S.; Shipley, B.; Shovon, T.A.; Siebenkäs, A.; Sierra, C.; Silva, V.; Silva, M.; Tommaso, S.; Sjöman, H.; Slot, M.; Smith, N.G.; Sodhi, D.; Soltis, P.; Soltis, D.; Somers, B.; Sonnier, G.; Sørensen, M.V.; Sosinski-Jr., E.E.; Soudzilovskaia, N.A.; Souza, A.F.; Spasojevic, M.; Sperandii, M.G.; Stan, A.B.; Stegen, J.; Steinbauer, K.; Stephan, J.G.; Sterck, F.; Stojanovic, D.B.; Strydom, T.; Suarez, M.L.; Svenning, J.-C.; Svitková, I.; Svitok, M.; Svoboda, M.; Swaine, E.; Swenson, N.; Tabarelli, M.; Takagi, K.; Tappeiner, U.; Tarifa, R.; Tauugourdeau, S.; Tavsanoglu, C.; te Beest, M.; Teders0o, L.; Thiffault, N.; Thom, D.; Thomas, E.; Thompson, K.; Thornton, P.E.; Thuiller, W.; Tichý, L.; Tissue, D.; Tjoelker, M.G.; Tng, D.Y.P.; Tobias, J.; Török, P.; Tarin, T.; Torres-Ruiz, J.M.; Tóthmérész, B.; Treurnicht, M.; Trivellone, V.; Trolliet, F.; Trotsiuk, V.; Tsakalos, J.L.; Tsiripidis, I.; Tysklind, N.; Umehara, T.; Usoltsev, V.; Vadeboncoeur, M.; Vaezi, J.; Valladares, F.; Vamosi, J.; van Bodegom, P.M.; van Breugel, M.; Cleemput, E.V.; van de Weg, M.; van der Merwe, S.; van der Plas, F.; van der Sande, M.T.; van Kleunen, M.; Van Meerbeek, K.; Vanderwel, M.; Vanselow, K.A.; Vårhammar, A.; Varone, L.; 
Valderrama, M.Y.V.; Vassilev, K.; Vellend, M.; Veneklaas, E.J.; Verbeeck, H.; Verheyen, K.; Vibrans, A.; Vieira, I.; Villacís, J.; Violle, C.;Vivek, P.; Wagner, K.; Waldram, M.; Waldron, A.; Walker, A.P.; Waller, M.; Walther, G.; Wang, H.; Wang, F.; Wang, W.; Watkins, H.; Watkins, J.; Weber, U.; Weedon, J.T.; Wei, L.; Weigelt, P.; Weiher, E.; Wells, A.W.; Wellstein, C.; Wenk, E.; Westoby, M.; Westwood, A.; White, P.J.; Whitten, M.; Williams, M.; Winkler, D.E.; Winter, K.; Womack, C.; Wright, I.J.; Wright, S.J.; Wright, J.; Pinho, B.X.; Ximenes, F.; Yamada, T.; Yamaji, K.; Yanai, R.; Yankov, N.; Yguel, B.; Zanini, K.J.; Zanne, A.E.; Zelený, D.; Zhao, Y.-P.; Zheng, J.; Zheng, J.; Ziemińska, K.; Zirbel, C.R.; Zizka, G.; Zo-Bi, I.C.; Zotz, G. \& Wirth, C. 2020. TRY plant trait database - enhanced coverage and open access. Global Change Biology, 26: 119-188.

Keddy, P.A. 1992. Assembly and response rules: two goals for predictive community ecology. Journal of Vegetation Science, 3: 157-164.

Kerth, G. 2008. Causes and consequences of sociality in bats. Bioscience, 58(8): 737-746.

King, J.; Carmona-Galindo, V.; Schomer, C. \& Sheridan, K. 2013. Correlaciones Exploratorias Entre Parámetros de Ecolocalización y Morfometría de la Hoja Nasal y Alas en Murciélagos de la Familia Phyllostomidae. Mesoamericana, 17(2): 31-37.

Kleiber, M. 1947. Body size and the metabolic rate. Physiological Reviews, 27(4): 511-541.

Kleyer, M.; Bekker, R.M.; Knevel, I.V.; Bakker, J.P; Thompson, K.; Sonneschein, M.; Poschold, P.; Groenendael, J.M.; Klimes, L.; Klimesova, J.; Klotz, S.; Rusch, G.M.; Hermy, M.; Adriens, D.; Boedeltje, G.; Bossuyt, B.; Dannemann, D.; Ozinga, W.A.; Romermman, C.; Stadler, M.; Schlegelmilch, J.; Steendman, H.J.; Tackenberg, 0.; Wilmann, B.; Cornelissen, J.H.C.; Eriksson 0.; Garnier, E. \& Peco, B. 2008. The LEDA Traitbase: a database of life-history traits of the Northwest European flora. Journal of Ecology, 96: 1266-1274.

Klug, B. \& Barclay, M.R. 2013. Thermoregulation during reproduction in the solitary, foliage-roosting hoary bat (Lasiurus cinereus). Journal of Mammalogy, 94(2): 477-487.

Kunz, T.H. 1982. Roosting ecology. In: Kunz, T.H. (Ed.). Ecology of Bats. New York, Plenum Press. p. 1-46.

Kunz, T.H.; Adams, R.A. \& Hood, W.R. 2009. Methods for assessing size at birth and postnatal growth and development in bats. In: Kunz, T.H. \& Parsons, S. (Eds.). Ecological and behavioral methods for the study of bats. Michigan, Johns Hopkins University Press, p. 274-314.

Kunz, T.H.; Torrez, E.B.; Bauer, D.; Lobova, T. \& Fleming, T.H. 2011. Ecosystem services provided by bats. Annals of the New York Academy of Sciences, 1223: 1-38.

Kunz, T.H.; Whitaker, J.O. \& Wadanoli, M.D. 1995. Dietary energetics of the insectivorous Mexican free-tailed bat (Tadarida brasiliensis) during pregnancy and lactation. Oecologia, 101(4): 407-415.

Lacher, T.E.; Davidson, A.D.; Fleming, T.H.; Gómez-Ruiz, E.P.; McCracken, G.F.; Owen-Smith, N.; Peres, C.A. \& VanderWall, S.B. 2019. The functional roles of mammals in ecosystems. Journal of Mammalogy, 100(3): 942-964.

Laska, M. 1990. Food transit times and carbohydrate use in three Phyllostomids bat species. Zeitschrift für Säugetierkunde, 55: 49-54.

Laurindo, R.S.; Vizentin-Bugoni, J.; Tavares, D.C.; Mancini, M.C.S.; Mello, R.M. \& Gregorin, R. 2020. Drivers of bat roles in Neotropical seed dispersal networks: abundance is more important than functional traits. Oecologia, 193: 189-198.

Lavorel, S. \& Garnier, E. 2002. Predicting changes in community composition and ecosystem functioning from plant traits: revisiting the Holy Grail. Functional Ecology, 16(5): 545-556.

Lavorel, S.; McIntyre, S.; Landsberg, J. \& Forbes, T. 1997. Plant functional classifications: from general groups to specific groups based on response to disturbance. Trends in Ecology and Evolution, 12(12): 474-478.
Lisón, F. 2012. Datos biométricos de cinco especies de murciélagos (Mammalia: Chiroptera) de la Región de Murcia (SE España). Anales de Biología, 34: 37-42.

Loayza, A. \& Loiselle, B.A. 2008. Preliminary Information on the Home Range and Movement Patterns of Sturnira lilium (Phyllostomidae) in a Naturally Fragmented Landscape in Bolivia. Biotropica, 40(5): 630-635.

Loayza, A.P.; Rios, R.S. \& Larrea Alcázar, D.M. 2006. Disponibilidad de recurso y dieta de murciélagos frugívoros en la Estación Biológica Tunquini, Bolivia. Ecología en Bolivia, 41(1): 7-23.

López, J. \& Vaughan, C. 2004. Observations on the Role of Frugivorous Bats as Seed Dispersers in Costa Rican Secondary Humid Forests. Acto Chiropterologica, 6(1): 111-119.

López-Cuamatzi, I.L.; Vega-Gutierrez, V.H.; Cabrera-Campos, I.; Ruíz-Sanchez, E.; Ayala-Berdon, J. \& Saldaña-Vázquez, R.A. 2020. Does body mass restrict call peak frequency in echolocating bats? Mammal Review, 50(3): 304-313.

López-Ordoñez, J.P.; Stiles, G. \& Parra-Vergara, J.L. 2015. Protocolo para la medición de rasgos funcionales en aves, In: Salgado-Negret, B. (Ed.). La Ecología funcional como aproximación al estudio, manejo y conservación de la biodiversidad: protocolos y aplicaciones. Bogotá, Instituto de Investigación de Recursos Biológicos Alexander von Humboldt (IAvH). p. 80-126.

Louzada, N. \& Pessôa, L. 2013. Morphometric differentiation of Glossophaga soricina soricina (Chiroptera: Phyllostomidae) in three Brazilian biomes. Zoologia, 30(4): 419-423.

Luck, G.; Lavorel, S.; McIntyre, S. \& Lumb, K. 2012. Improving the application of vertebrate trait-based frameworks to the study of ecosystem services. Journal of Animal Ecology, 81(5): 1065-1076.

MacArthur, R. \& Pianka, E. 1966. On optimal use of a patchy environment. American Naturalist, 100(916): 603-609.

MacNab, B.K. 2003. Standard energetics of phyllostomid bats: the inadequacies of phylogenetic-contrast analyses. Comparative Biochemistry and Physiology, Molecular \& Integrative Physiology, 135 A(3): 357-368.

MacNab, B.K. 2007. The evolution of energetics in birds and mammals. In: Kelt, D.A.; Lessa, E.P.; Salazar-Bravo, J. \& Patton, J.L. (Eds.). The Quintessential Naturalist: Honoring the Life and Legacy of Oliver P. Pearson. Los Angeles, University of California Publications. p. 67-110.

Magalhães de Oliveira, H.F.; Camargo, N.F.; Hemprich-Bennett, D.R.; Rodríguez-Herrera, B.; Rossiter, S.J. \& Clare, E.L. 2020 Wing morphology predicts individual niche specialization in Pteronotus mesoamericanus (Mammalia: Chiroptera). Plos One, 15(5): e0232601. D01

Makanya, A. \& Mortola, J. 2007. The structural design of the bat wing web and its possible role in gas exchange. Journal of Anatomy, 211(6): 687-697.

Mammal Diversity Database. 2020. American Society of Mammalogists. Available: http://www.mammaldiversity.org. Access: 10/07/2020.

Mancini, M.C.S.; Laurindo, R.S.; Hintze, F. Mello, R.M. \& Gregorin, R. 2019. Different bat guilds have distinct functional responses to elevation. Acta Oecologica, 96: 35-42.

Marinello, M.M. \& Bernard, E. 2014. Wing morphology of Neotropical bats: a quantitative and qualitative analysis with implications for habitat use. Canadian Journal of Zoology, 92(2): 141-147.

Martínez-Ferreira, S.R.; Alvarez-Añorve, M.Y.; Bravo-Monzón, A.E.; MontielGonzález, C.; Flores-Puerto, J.I.; Morales-Díaz, S.P.; Chiappa-Carrara, X.; Oyama, K. \& Avila-Cabadilla, L.D. 2020. Taxonomic and Functional Diversity and Composition of Bats in a Regenerating Neotropical Dry Forest. Diversity, 12: 332. DOI

Mayfield, M.M.; Bonser, S.P.; Morgan, J.W.; Aubin, I.; McNamara, S. \& Vesk, P.A. 2010. What does species richness tell us about functional trait diversity? Predictions and evidence for responses of species and functional trait 
diversity to land-use change. Global Ecology and Biogeography, 19(4): 423-431.

McCain, C. 2007. Could temperature and water availability drive elevational species richness patterns? A global case study for bats. Global Ecology and Biogeography, 16: 1-13.

McCracken, G.F.; Westbrook, J.K.; Brown, V.A.; Eldridge, M.; Federico, P. \& Kunz, T.H. 2012. Bats Track and Exploit Changes in Insect Pest Populations. Plos One, 7(8): e43839. DOI

McGill, B.J.; Enquist, B.J.; Weiher, E. \& Westoby, M. 2006. Rebuilding community ecology from functional traits. Trends in Ecology and Evolution, 21(4): 178-185.

McGuire, L.P. \& Boyle, W.A. 2013. Altitudinal migration in bats: evidence, patterns, and drivers. Biological Reviews, 88(4): 767-786.

Medellín, R.A.; Equihua, M. \& Amin, M.A. 2000. Bat diversity and abundance as indicators of disturbance in Neotropical rainforests. Conservation Biology, 14(6): 1666-1675.

Mello, M.A.R. \& Fernandez F.A.S. 2000. Reproductive ecology of the bat Carollia perspicillata (Chiroptera: Phyllostomidae) in a fragment of the Brazilian Atlantic coastal forest. Zeitschrift für Säugetierkunde, 65(6): 340-349.

Mello, M.A.R.; Kalko, E.K.V. \& Silva, W.R. 2008. Movements of the bat Sturnira lilium and its role as a seed disperser of Solanaceae in the Brazilian Atlantic forest. Journal of Tropical Ecology, 24(2): 225-228.

Mello, M.A.R.; Schittini, G.M.; Selig, P. \& Bergallo, H.G. 2004. A test of the effects of climate and fruiting of Piper species (Piperaceae) on reproductive patterns of the bat Carollia perspicillata (Phyllostomidae). Acta Chiropterologica, 6(2): 309-318.

Meyer, C.F.J.; Fründ, J.; Lizano, W.P. \& Kalko, E.K.V. 2008. Ecological correlates of vulnerability to fragmentation in Neotropical bats. Journal of Applied Ecology, 45(1): 381-391.

Meyer, C.F.J.; Struebig, M.J. \& Willig, M.R. 2016. Responses of Tropical Bats to Habitat Fragmentation, Logging, and Deforestation. In: Voigt, C. \& Kingston, T. (Eds.). Bats in the Anthropocene: Conservation of Bats in a Changing World. Cham, Springer. p. 63-103.

Mikich, S.B.; Bianconi, G.V.; Maia, B.H.L.N.S. \& Teixeira, S.D. 2003. Attraction of the fruit-eating bat Carollia perspicillata to Piper gaudichaudianum essential oil. Journal of Chemical Ecology, 29(10): 207-217.

Millennium Ecosystem Assessment. 2005. Ecosystems and human well being: synthesis. Washington, Island Press.

Mlambo, M.C. 2014. Not all traits are 'functional': insights from taxonomy and biodiversity-ecosystem functioning research. Biodiversity and Conservation, 23(3): 781-790.

Montaño-Centellas, F.; Moya, M.l.; Aguirre, L.F.; Galeon, R.; Palabrala, 0.; Hurtado, R.; Galarza, I.\& Tordoya, J. 2015. Community and species-level responses of phyllostomid bats to a disturbance gradient in the tropical Andes. Acta Oecologica, 62: 10-17.

Monteiro, L. \& Nogueira, M. 2010. Adaptive radiations, ecological Specialization, and the evolutionary Integration of complex morphological structures. Evolution, 64(3): 724-744.

Montiel, S.; Estrada, A. \& Leon, P. 2011. Reproductive seasonality of fruiteating bats in northwestern Yucatán, México. Acta Chiropterologica, 13: 139-145.

Mora-Fernández, C.; Peñuela-Recio, L.; Angarita-Sierra, T.; Cabrera-Amaya, D.; Suárez-Castro, F.; López-Ordoñez, J.; Salazar-Bermúdez, V.; González, J.; Bonilla-Urbano, A.; Maldonado-Ocampo, J. \& Castro-Lima, F. 2013. Propuesta de indicadores para la evaluación de la salud ecosistémica de las sabanas inundables de la Orinoquia y resultados de la salud de las sabanas asociadas a la Cuenca del Ríos Pauto. In: Mora-Fernandez, C. \& PeñuelaRecio, L. (Eds.). Salud Ecosistémica de las sabanas inundables asociadas a la Cuenca del rio Pauto, Casanare, Colombia. Bogotá, Yoluka. p. 76-150.
Moretti, M.; Dias, A.T.C.; de Bello, F.; Altermatt, F.; Chown, S.L.; Azcárate, F.M.; Bell, J.R.; Fournier, B.; Hedde, M.; Hortal, J.; Ibañez, S.; Öckinger, E.; Sousa, J.P.; Ellers, J. \& Berg, M.P. 2017. Handbook of protocols for standardized measurement of terrestrial invertebrate functional traits. Functional Ecology, 31(3): 558-567.

Muchhala, N. 2006. The pollination biology of Burmeistera (Campanulaceae): specialization and syndromes. American Journal of Botany, 93:1081-1089.

Muchhala, N. \& Thomson, J.D. 2010. Fur versus feathers: pollen delivery by bats and hummingbirds and consequences for pollen production. American Naturalist, 175(6): 717-726.

Muise, K.A.; Menzies, A.K. \& Willis, C.K.R. 2018. Stress-induced changes in body temperature of silver-haired bats (Lasionycteris noctivagans). Physiology \& Behavior, 194: 356-361.

Müller, R. 2004. A numerical study of the role of the tragus in the big brown bat. The Journal of the Acoustical Society of America, 116(6): 3701-3712.

Muñoz, J. 2001. Murciélagos de Colombia: sistemática, distribución, descripción, historia natural y ecología. Antioquia, Editorial Universidad de Antioquia.

Murray, K.G.; Russell, S.; Picone, C.M.; Winnett-Murray, K.; Sherwood, W. \& Kuhlmann, M.L. 1994. Fruit laxatives and seed passage rates in frugivores: consequences for plant reproductive success. Ecology, 75(4): 989-994.

Muscarella, R. \& Fleming, T.H. 2007. The role of frugivorous bats in tropical forest succession. Biological Reviews, 82(4): 573-590.

Myers, P.; Espinosa, R.; Parr, C.S.; Jones, T.; Hammond, G.S. \& Dewey, T.A. 2016. The Animal Diversity Web (online). Available: http://animaldiversity.org. Access: 24/07/2020.

Naranjo, M.E.; Renjifo, C. \& Soriano, P.J. 2003. Effect of Ingestion by Bats and Birds on Seed Germination of Stenocereus griseus and Subpilocereus repandus (Cactaceae). Journal of Tropical Ecology, 19(1): 19-25.

Neuweiler, G. 2000. Echolocation. In: Neuweiler, G. (Ed.). The Biology of bats. 0xford, Oxford University Press. p. 140-260.

Nogueira, M.R.; Peracchi, A.L. \& Monteiro, L.R. 2009. Morphological correlates of bite force and diet in the skull and mandible of phyllostomid bats. Functional Ecology, 23(4): 715-723.

Norberg, U.M. 1990. Vertebrate flight. Mechanics, physiology, morphology, ecology and evolution. Berlin, Springer-Verlag.

Norberg, U.M. 1994. Wing design, flight performance, and habitat use in bats. In: Wainwright, I.C. \& Reilly, S.M. (Eds.). Ecological morphology: integrative organismal biology. Chicago, University of Chicago Press. p. 205-239.

Norberg, U.M. \& Fenton, M.B. 1988. Carnivorous bats? Biological Journal of Linnean Society, 33(4): 383-394.

Norberg, U.M. \& Norberg, R.Å. 2012. Scaling of wingbeat frequency with body mass in bats and limits to maximum bat size. Journal of Experimental Biology, 215(5): 711-722.

Norberg, U.M. \& Rayner, J.M. 1987. Ecological morphology and flight in bats (Mammalia; Chiroptera): wing adaptations, flight performance, foraging strategy and echolocation. Philosophical Transactions of the Royal Society B: Biological Sciences, 316: 335-427.

Núñez, S.F.; López-Baucells, A.; Rocha, R.; Farneda, F.Z.; Bobrowiec, P.E.D.; Palmeirim, J.M. \& Meyer, C.F.J. 2019. Echolocation and Stratum Preference: Key Trait Correlates of Vulnerability of Insectivorous Bats to Tropical Forest Fragmentation. Frontiers Ecology and Evolution, 7: 373. DOI

O'Mara, M.T.; Rikker, S.; Wikelski, M.; Ter Maat, A.; Pollock, H.S. \& Dechmann, D.K.N. 2017. Heart rate reveals torpor at high body temperatures in lowland tropical free-tailed bats. Royal Society Open Science, 4: 171359. DOI

Obrist, M.; Fenton, B.; Egerj, J. \& Schlegel, P. 1993. What ears do for bats: a comparative study of pinna sound pressure transformation in chiroptera. Journal of Experimental Biology, 180: 119-152. 
Olaya-Rodríguez, H.; Pérez-Torrez, J. \& Londoño, M.C. 2019 Use of forest strata by bats according to wing morphology and habitat complexity in a fragment of tropical dry forest (Colombia). Journal of Bat Research and Conservation, 12(1): 83-91.

Oliveira, A.K.M. \& Lemes, F.T.F. 2010. Artibeus planirostris como dispersor e indutor de germinação em uma área do Pantanal do Negro, Mato Grosso do Sul, Brasil. Revista Brasileira de Biociências, 8(1): 49-52.

Ortega-García, S.; Ferreyra-García, D. \& Schoundube, J.E. 2020. Gut reaction! Neotropical nectar-feeding bats responses to direct and indirect costs of extreme environmental temperatures. Journal of Comparative Physiology B, 190:655-667. D0I

Pastor, J.F.; Moro, J.A.; Verona, J.A.G.; Gato, A.; Represa, J.J. \& Barbosa, E. 1993. Morphological study by scanning electron microscopy of the lingual papillae in the common European bat (Pipisterllus pipisterllus). Archive's of Oral Biology, 38(7): 597-599.

Patterson, B.; Willig, M. \& Stevens, R. 2003. Trophic strategies, niche partioning, and patterns of ecology organization. In: Kunz, T.H. \& Fenton, B. (Eds.). Bat Ecology. Chicago, University of Chicago Press. p. 536-579.

Pereira, A.D.; de Lima, I.P. \& dos Reis, N.R. 2019. Changes in Bat Diversity in Agrosystems in the Atlantic Rain Forest, Brazil. Mastozoología Neotropical, 26(1): 155-166

Pereira, A.S.; da Rocha, P.A.; Santana, J.P.; Beltrão, R.; Iruiz-Esparza, J. \& Ferrari, F. 2017. Consumption of leaves by Carollia perspicillata (Chiroptera, Phyllostomidae): a new dimension of the species' feeding ecology. Mammalia, 82: 1-5.

Pereira, M.; Fonseca, C. \& Aguiar, L.M.S. 2018. Loss of multiple dimensions of bat diversity under land-use intensification in the Brazilian Cerrado. Hystrix, 29(1): 25-32.

Pereira, M.; Marques, J.T. \& Palmeirim, J.M. 2010. Vertical stratification of bat assemblages in flooded and unflooded Amazonian forests. Current Zoology, 56(4): 469-478.

Pérez-Torres, J. 2004. Dinámica del ensamblaje de murciélagos en respuesta a la fragmentación en bosques nublados: un modelo de ecuaciones. (Doctoral Thesis). Pontificia Universidad Javeriana, Bogotá (Colombia).

Pierson, E.D. 1998. Tall trees, deep holes, and scarred landscapes: conservation biology of North American bats. In: Kunz, T.H. \& Racey, P.A. (Eds.). Batbiology and conservation. Washington, Smithsonian Institution Press. p. 309-324.

Presley, S.J.; Cisneros, L.M.; Higgins, C.L.; Klingbeil, B.T.; Scheiner, S.M. \& Willig, M.R. 2017. Phylogenetic and functional underdispersion in Neotropical phyllostomid bat. Biotropica, 50(1): 135-145

Presley, S.J.; Willig, M.R.; Castro-Arellano, I. \& Weaver, S. 2009. Effects of habitat conversion on temporal activity patterns of phyllostomid bats in lowland Amazonian rain forest. Journal of Mammalogy, 90(1): 210-221.

Quesada, M.; Stoner, K.E.; Rosas-Guerrero, V.; Palacios-Guevara, C. \& Lobo, J.A. 2003. Effects of habitat disruption on the activity of nectarivorous bats (Chiroptera: Phyllostomidae) in a dry tropical forest: implications for the reproductive success of the neotropical tree (eiba grandiflora. Oecologia, 135(3): 400-406.

Quinn, T. \& Baumel, J. 1993. Chiropteran tendon locking mechanism. Journal of Morphology, 216(2): 197-208.

Ramírez-Mejía, A.F.; Urbina-Cardona, J.N. \& Sánchez, F. 2020. Functional diversity of phyllostomid bats in an urban-rural landscape: A scaledependent analysis. Biotropica, 52(6): 1-15. DOI

Razak, K.A. 2018. Adaptations for substrate gleaning in bats: the pallid bat as a case study. Brain Behavior and Evolution, 91(2): 97-108.

Reeder, W.G. \& Cowles, R.B. 1951. Aspects of Thermoregulation in Bats. Journal of Mammalogy, 32(4): 389-403.

Rex, K.; Michener, R.; Kunz, T.H. \& Voigt, C.C. 2011. Vertical stratification of Neotropical leaf-nosed bats (Phyllostomidae: Chiroptera) revealed by stable carbon isotopes. Journal of Tropical Ecology, 27: 211-222.
Robbirt, K.M.; Davy, A.J.; Hutchings, M.J. \& Roberts, D.L. 2011. Validation of biological collections as a source of phenological data for use in climate change studies: A case study with the orchid Ophrys sphegodes. Journal of Ecology, 99: 235-241.

Rocha, R.; López-Baucells, A.; Farneda, F.Z.; Groenenberg, M.; Bobrowiec, P.E.D.; Cabeza, M.; Palmeirim, J.M. \& Meyer, C.F.J. 2017. Consequences of a large-scale fragmentation experiment for Neotropical bats: disentangling the relative importance of local and landscapescale effects. Landscape Ecology, 32: 31-45.

Rodrigues Coelho, E.; Paglia, A.P.; Viana-Junior, A.B.; Falcão, L.A.D. \& Ferreira, G.B. 2018. Species Richness, Abundance and Functional Diversity of a Bat Community along an Elevational Gradient in the Espinhaço Mountain Range, Southeastern Brazil. Acta Chiropterologica, 20(1): 129-138.

Rodríguez-Durán, A. \& Padilla-Rodríguez, E. 2008. Blood Characteristics, Heart Mass, and Wing Morphology of Antillean Bats. Caribbean Journal of Science, 44(3): 375-379.

Rubach, M.N.; Ashauer, R.; Buchwalter, D.B.; De Lange, H.J.; Hamer, M.; Preuss, T.G.; Topke, K. \& Maund, S.J. 2011. Framework for traits-based assessment in ecotoxicology. Integrated Environmental Assessment and Management, 7: 172-186.

Safi, K.; Meiri, S. \& Jones, K.E. 2013. Body mass evolution in bats. In: Smith, F.A. \& Lyons, S.K. (Eds.). Animal body size: Linking pattern and process across space, time, and taxonomic group. Chicago, Chicago University Press. p. 95-151.

Saldaña-Vázquez, R.A. 2014a. Intrinsic and extrinsic factors affecting dietary specialization in Neotropical frugivorous bats. Mammal Review, 44: 215-224.

Saldaña-Vázquez, R.A. 2014b. Convergencia y señal filogenética: el caso de los sonidos de ecolocación en murciélagos. Boletín Red Latinoamericana de Conservación de Murciélagos, 5(3): 3-8.

Saldaña-Vázquez, R.A. \& Munguía-Rosas, M.A. 2013. Lunar phobia in bats and its ecological correlates: A meta-analysis. Mammalian Biology, 78(3): 216-219.

Saldaña-Vázquez, R.A. \& Schondube, J.E. 2013. Food intake changes in relation to food quality in the Neotropical frugivorous bat Sturnira ludovici. Acta Chiropterologica, 15: 69-75.

Saldaña-Vázquez, R.A. \& Schondube, J.E. 2016. La masa corporal explica la dominancia de Artibeus (Phyllostomidae) en ambientes urbanos. In: Ramírez-Bautista, A. \& Pineda-López, R. (Eds.). Memorias en Extenso del I Congreso de Fauna Nativa en Medios Antropizados. México, CONCYT-UAQ p. 23-33.

Saldaña-Vázquez, R.A.; Castaño, J.H.; Baldwin, J. \& Pérez-Torres, J. 2019. Does seed ingestion by bats enhance germination? A new meta-analysis 15 years later. Mammal Review, 49(3): 201-209.

Saldaña-Vázquez, R.A.; Ortega, J.; Guerrero, J.A.; Aiza-Reynoso, M.l.; MacSwiney, M.C.; Aguilar-Rodríguez, P.A.; Ayala-Berdon, J. \& ZamoraGutierrez, V. 2020. Ambient temperature drives sex ratio and presence of pregnant females of Anoura geoffroyi (Phyllostomidae) bats living in temperate forests. Journal of Mammalogy, 101(1): 234-240.

Saldaña-Vázquez, R.A.; Ruiz-Sanchez, E.; Herrera-Alsina, L. \& Schondube, J. 2015. Digestive capacity predicts diet diversity in Neotropical frugivorous bats. Journal of Animal Ecology, 84: 1-9.

Salgado-Negret, B.; Pulido-Rodríguez, E.N.; Cabrera, M.; Ruiz-Osorio, C. \& Paz, H. 2015. Protocolo para la medición de rasgos funcionales en plantas, In: Salgado-Negret, B. (Ed.). La Ecología funcional como aproximación al estudio, manejo y conservación de la biodiversidad: protocolos y aplicaciones, Bogotá, Instituto de Investigación de Recursos Biológicos Alexander von Humboldt (IAvH). p. 37-79.

Sampedro, A.C.; Martínez, C.M.; Mercado, A.M.; Osorio, S.C.; Oteroy, Y.L. \& Santos, L.M. 2008. Refugios, período reproductivo y composición social 
de las poblaciones de Desmodus rotundus (Geoffroy, 1810) (Chiroptera: Phyllostomidae), en Zonas Rurales del Departamento de Sucre, Colombia. Caldasia, 30: 127-134.

Santana, D. 2015. Quantifying the effect of gape and morphology on bite force: biomechanical modelling and in vivo measurements in bats. Functional ecology, 30(4): 557-565.

Santana, S.; Grosse, I. \& Dummont, E. 2012. Dietary hardness, loading behavior, and the evolution of skull form in bats. Evolution, 66(8): 2587-2598.

Santana, S.E.; Strait, S. \& Dumont, E.R. 2011a. The better to eat you with: functional correlates of tooth structure in bats. Functional Ecology, 25(4): 839-847.

Santana, S.E.; Dial, T.O.; Eiting, T.P. \& Alfaro, M.E. 2011b. Roosting ecology and the evolution of pelage markings in bats. Plos One, 6: e25845. DOI

Saunders, M. \& Barclay, R. 1992. Ecomorphology of insectivorous bats: a test of predictions using two morphologically similar species. Ecology, 73(4): 1335-1345.

Sazima, M.; Buzato, S. \& Sazima, I. 2003. Dyssochroma viridiflorum (Solanaceae): A reproductively bat-dependent epiphyte from the Atlantic rainforest in Brazil. Annals of Botany, 92: 725-730.

Schnitzler, H-U. \& Kalko, E. 2001. Echolocation by insect-eating bats. Bioscience, 51(7): 557-569.

Schnitzler, H-U.; Moss, C.; Denzinger, A. 2003. From spatial orientation to food acquisition in echolocating bats. Trends in Ecology and Evolution, 18: 386-394.

Schoener, T. 1971. Theory of feeding strategies. Annual Review of Ecology and Systematics, 2: 369-404.

Schondube, J.E.; Herrera, G. \& Martínez del Río, C. 2001. Diet and the evolution of digestion and renal function in phyllostomid bats. Zoology Analysysis of Complex Systems, 104(1): 59-73.

Schupp, E.W.; Jordano, P. \& Gómez, J.M. 2010. Seed dispersal effectiveness revisited: a conceptual review. New Phytologist, 188: 333-353.

Sears, K.; Behringer, R.; Rasweiler, J. \& Niswander, I. 2006. Development of bat flight: Morphologic and molecular evolution of bat wing digits. Proceedings of the National Academy of Sciences, 103(17): 6581-6586.

Sherwin, H.A.; Montgomery, W.I. \& Lundy, M.G. 2012. The impact and implications of climate change for bats: Bats and climate change. Mammal Review, 43: 171-182.

Shilton, L.A.; Altringham, J.D.; Compton, S.G. \& Whittaker, R.J. 1999. Old world fruit bats can be long-distance seed dispersers through extended retention of viable seeds in the gut. Proceedings of the Royal Society $B$. Biological Sciences, 266: 219-223.

Siefert, A.; Violle, C.; Chalmandrier, L.; Taudiere, A.; Lonnie, A.F.; Aarssen, W.; Baraloto, C.; Carlucci, M.B.; Cianciaruso, M.V.;Dantas, V.; de Bello, F.; Duarte, L.D.S.; Fonseca, C.R.; Freschet, G.T.; Gaucherand, S.; Gross, N.; Hikosaka, K.; Jackson, B.; Jung, V.; Kamiyama, C.; Katabuchi, M.; Kembel, S.W.; Kichenin, E.; Kraft, N.J.B.; Lagerström, A.; Le Bagousse-Pinguet, Y.; Li, Y.; Mason, N.; Messier, J.; Nakashizuka, T.; McC. Overton, J.; Peltzer, D.A.; Pérez-Ramos, I.M.; Pillar, V.D.; Prentice, H.C.; Richardson, S.; Sasaki, T.; Schamp, B.S.; Schöb, C.; Shipley, B.; Sundqvist, M.; Sykes, M.T.; Vandewalle, M. \& Wardle, D.A. 2015. A global meta-analysis of the relative extent of intraspecific trait variation in plant communities. Ecology Letters, 18(12): 1406-1419.

Soriano, P. 2000. Functional structure of bat communities in tropical rainforests and andean cloud forests. Ecotropicos, 13(1): 1-20.

Soriano, P.J.; Ruiz, A. \& Arends, A. 2002. Physiological responses to ambient temperature manipulation by three species of bats from Andean cloud forests. Journal of Mammalogy, 83(2): 445-457.

Speakman, J.R. 2008. The physiological costs of reproduction in small mammals. Philosophical Transactions of the Royal Society of London B. Biological Sciences, 363(1490): 375-398.
Stevens, R.; Johnson, M. \& McCulloch, E. 2013. Absolute and relative secondary-sexual dimorphism in wing morphology: a multivariate test of the 'Big Mother' hypothesis. Acta Chiropterologica, 15(1): 163-170.

Stockwell, E.F. 2001. Morphology and fight manoeuvrability in New World leaf-nosed bats (Chiroptera: Phyllostomidae). Journal of Zoology, 254(4): 505-514.

Stoddart, D.M. 1979. External nares and olfactory perceptions. Experimentia, 35(11): 1456-1457.

Stukenholtz, E.; Stevens, R. \& Pérez-Torres, J. 2018. Variation of vaginal cytology, progesterone and estradiol metabolites in Seba's shorttailed fruit bat during the estrous cycle and gestation. Mastozoologia Neotropical, 25(1): 151-162.

Surlykke, A. \& Kalko, E.K.V. 2008. Echolocating bats cry out loud to detect their prey. Plos One, 3(4): e2036. DOI

Swartz, S.M. \& Middleton, K.M. 2008. Biomechanics of the bat limb skeleton: scaling, material properties and mechanics. Cell Tissues Organs, 187: 59-84.

Thiagavel, J.; Santana, S.E. \& Ratcliffe, J.M. 2017. Body size predicts echolocation call peak frequency better than gape height in vespertilionid bats. Scientific Reports, 7: 828. D0I

Thies, W. \& Kalko, E.K.V. 2004. Phenology of neotropical pepper plants (Piperaceae) and their association with their main dispersers, two shorttailed fruit bats, Carollia perspicillata and C. castanea (Phyllostomidae). Oikos, 104(2): 362-376.

Thies, W.; Kalko, E.K.V. \& Schnitzler, H.U. 2006. Influence of environment and resource availability on activity patterns of Carollia castanea (Phyllostomidae) in Panamá. Journal of Mammalogy, 87(2): 331-338.

Thollesson, M. \& Norberg, U.M. 1991. Moments of inertia of bat wings and body. Journal of Experimental Biology, 158: 19-35.

Traveset, A. 1998. Effect of seed passage through vertebrate frugivores' guts on germination: a review. Perspectives in Plant Ecology, Evolution and Systematics, 1: 151-190.

Tschapka, M. 2003. Pollination of the understorey palm Calyptrogyne ghiesbreghtiana by hovering and perching bats. Biological Journal of the Linnean Society, 80(2): 281-288.

Tschapka, M.; Gonzalez-Terrazas, T.P. \& Knörnschild, M. 2015. Nectar uptake in bats using a pumping-tongue mechanism. Science Advance, 1(8): e1500525. DOI

Uieda, W. \& Vasconcellos-Neto, J. 1984. Dispersão de Solanum spp. (Solanaceae) por morcegos, na região de Manaus, AM, Brasil. Revista Brasileira de Zoologia, 2(7): 449-458.

Van den Brink, P.J.; Baird, D.J.; Baveco, H. \& Focks, A. 2013. The use of traits-based approaches and eco(toxico)logical models to advance the ecological risk assessment framework for chemicals. Integrated Environmental Assessment and Management, 9(3): E47-E57. DOI

Vandoros, J.D. \& Dumont, E.R. 2004. Use of the wings in manipulative and suspensory behaviors during feeding by frugivorous bats. Journal of Experimental Zoology, 301A: 361-366.

Vela-Vargas, I.M.; Pérez-Torres, J.; Pérez-Pabón, L. \& Larrín, P. 2016. Vaginal smears: a key source of information on the estrous cycle of Neotropical bats. Mastozoloogía Neotropical, 23: 139-145.

Verde, R.S.; Silva, R.C. \& Calouro, A.M. 2018. Activity patterns of frugivorous phyllostomid bats in an urban fragment in southwest Amazonia, Brazil. Iheringia Série Zoologia, 108: 1-7.

Vieira, M.F. \& Carvalho-Okano, R.M. 1996. Pollination biology of Mabea fistulifera (Euphorbiaceae) in Southeastern Brazil. Biotropica, 28(1): 61-68.

Villéger, S.; Miranda, J.R.; Hernández, D.F. \& Mouillot, D. 2010. Contrasting changes in taxonomic vs. functional diversity of tropical fish communities after habitat degradation. Ecological Applications, 20(6): 1512-1522. 
Violle, C.; Enquist, B.J.; McGill, B.J.; Jiang, L.; Albert, C.H.; Hulshof, C.; Jung, V. \& Messier, J. 2012. The return of the variance: intraspecific variability in community ecology. Trends in Ecology \& Evolution, 27(4): 244-252.

Violle, C.; Navas, M.L.; Vile, D.; Kazakou, E.; Fortunel, C.; Hummel, I. \& Garnier, E. 2007. Let the concept of trait be functional. Oikos, 116(5): 882-892.

Voigt, C.; Borissov, I. \& Kelm, D.H. 2015. Bats Fertilize Roost Trees. Biotropica, 47(4): 403-406.

Voigt, C.C.; Schneeberger, K.; Voigt-Heucke, S.L. \& Lewanzik, D. 2011. Rain increases the energy cost of bat flight. Biology Letters, 7(5): 793-795.

Voss, R.S.; Fleck, D.W.; Strauss, R.E.; Velazco, P.M. \& Simmons, N.B. 2016. Roosting ecology of amazonian bats: evidence for guild structure in hyperdiverse mammalian communities. American Museum Novitates, 3870: 1-44.

Walldorf, V. \& Mehlhorn, H. 2013. Bats: A Glimpse on Their Astonishing Morphology and Lifestyle. In: Klimpel, S. \& Mehlhorn, H. (Eds.). Bats (Chiroptera) as Vectors of Diseases and Parasites Volume 5 of the series Parasitology Research Monographs. Berlin, Springer. p. 7-24.

Wang, Z.; Dong, D.; Ru, B.; Young, R.; Han, N.; Guo, T. \& Zhang, S. 2010. Digital gene expression tag profiling of bat digits provides robust candidates contributing to wing formation. BMC Genomics, 11: 619. D0I
Webster, F.A. \& Griffin, D.R. 1962. The role of flight membranes in insect capture by bats. Animal Behaviour, 10: 332-340.

Willig, M.; Patterson, B. \& Stevens, R. 2003. Patterns of range, size, richness, and body size in chiroptera. In: Kunz, T.H. \& Fenton, B. (Eds.). Bat Ecology. Chicago, Chicago University Press. p. 81-621.

Wilman, H.; Belmaker, J.; Simpson, J.; De La Rosa, C.; Rivadeneira, M.M. \& Jetz, W. 2014. EltonTraits 1.0: Species-level foraging attributes of the world's birds and mammals. Ecology, 95(7): 2027. D0I

Wilson, D.E. 1973. Bat faunas: a trophic comparison. Systematic Zoology, 22(1): 14-29.

Zamudio, J.E.; Herrera-Collazos, E.E.; Maldonado-Ocampo, J.A. \& DoNascimiento, C. 2015. Protocolo para la medición de rasgos funcionales en peces dulceacuícolas, In:Salgado-Negret, B. (Ed.). La Ecología funcional como aproximación al estudio, manejo y conservación de la biodiversidad: protocolos y aplicaciones. Bogotá, Instituto de Investigación de Recursos Biológicos Alexander von Humboldt (IAvH). p. 180-212. 